Original article

\title{
Modern sediments and Pleistocene reefs from isolated carbonate platforms (Iles Eparses, SW Indian Ocean): A preliminary study
}

\author{
Stéphan J. Jorry ${ }^{\mathrm{a},}{ }^{*}$, Gilbert F. Camoin ${ }^{\mathrm{b}}$, Gwénaël Jouet ${ }^{\mathrm{a}}$, Pascal Le Roy ${ }^{\mathrm{c}}$, Claude Vella ${ }^{\mathrm{b}}$, \\ Simon Courgeon ${ }^{a}$, Sophie Prat ${ }^{\mathrm{a}}$, Christophe Fontanier ${ }^{\mathrm{a}}$, Victorien Paumard ${ }^{\mathrm{d}}$, \\ Julien Boulle ${ }^{\mathrm{a}}$, Bruno Caline ${ }^{\mathrm{e}}$, Jean Borgomano ${ }^{\mathrm{b}, \mathrm{e}}$ \\ a IFREMER, Institut Carnot Edrome, Unité Géosciences Marines, Laboratoire Environnements Sédimentaires, 29280 Plouzané, France \\ b Aix-Marseille Université, CNRS, IRD, CEREGE UM34, 13545 Aix en Provence, France, B.P. 80, 13545 Aix-en-Provence, France \\ ' IUEM, Laboratoire Domaines Océaniques, 29280 Plouzané, France \\ d Centre for Energy Geoscience, School of Earth and Environment, University of Western Australia, 35 Stirling Highway, Crawley, WA 6009, Australia \\ e TOTAL Exploration and Production, CSTJF, Avenue Larribau, 64000 Pau, France
}

\section{A R T I C L E I N F O}

\section{Article history:}

Received 13 September 2015

Received in revised form 23 October 2015

Accepted 23 October 2015

\section{Keywords:}

Mozambique channel

Carbonate sediments

Fossil reefs

Isolated carbonate platforms

\begin{abstract}
A B S T R A C T
Isolated carbonate platforms occur throughout the geologic record, from Archean to present. Although the respective roles of tectonics, sediment supply and sea-level changes in the stratigraphical architecture of these systems are relatively well constrained, the details of the nature and controls on the variability of sedimentological patterns between and within individual geomorphologic units on platforms have been barely investigated. This study aims at describing and comparing geomorphological and sedimentological features of surficial sediments and fossil reefs from three isolated carbonate platforms located in the SW Indian Ocean (Glorieuses, Juan de Nova and Europa). These carbonate platforms are relatively small and lack continuous reef margins, which have developed only on windward sides. Field observations, petrographic characterization and grain-size analyses are used to illustrate the spatial patterns of sediment accumulation on these platforms. The internal parts of both Glorieuses and Juan de Nova platforms are blanketed by sand dunes with medium to coarse sands with numerous reef pinnacles. Skeletal components including coral, green algae, and benthic foraminifera fragments prevail in these sediments. Europa platform exhibits a similar skeletal assemblage dominated by coral fragments, with the absence of wave-driven sedimentary bodies. Fossil reefs from the Last interglacial (125,000 years BP) occur on the three platforms. At Glorieuses, a succession of drowned terraces detected on seismic lines is interpreted as reflecting the last deglacial sea-level rise initiated 20,000 years ago. These findings highlight the high potential of these platforms to study past sea-level changes and the related reef response, which remain poorly documented in the SW Indian Ocean.
\end{abstract}

(c) 2015 Elsevier Masson SAS. All rights reserved.

\section{Introduction}

Sedimentary models involving the distribution of carbonate sediments in modern systems are classically used as analogs to help in the interpretation of fossil carbonate platforms, especially to improve prediction of geometries, facies distribution and petrophysical heterogeneities in subsurface. Many studies dealing with sediment distribution in modern reefs and platforms have been carried out in the Atlantic (Florida Reef Tract: Ginsburg, 1956; Enos,

\footnotetext{
* Corresponding author.

E-mail address: stephan.jorry@ifremer.fr (S.J. Jorry).
}

1974; Great Bahama Bank: Purdy, 1963; Reijmer et al., 2009; Belize: Purdy and Gischler, 2003) and in the Pacific (Bikini: Emery et al., 1954; Hawaiian islands: Thorp, 1936; Gross et al., 1969; French Polynesia: Newell, 1956; Adjas et al., 1990; Gischler, 2011; Cook Islands; Tudhope et al., 1985; Great Barrier Reef: Maxwell, 1973). Conversely, similar investigations on Indian Ocean barrier reefs (Masse et al., 1989) and atolls (Gischler, 2006, 2011) are very rare.

Coral reefs are also markers of past sea levels, which are rather well constrained for the last glacial cycle (Lambeck and Chappell, 2001; Cutler et al., 2003; Siddall et al., 2003; Thompson and Goldstein, 2005), with a much better resolution for the last $20 \mathrm{ky}$ (Fairbanks, 1989; Bard et al., 1990; Edwards et al., 1993; Yokoyama et al., 2000; Camoin et al., 2004; Clark et al., 2004, 2009; Alley et al., 
2005; Bard et al., 2010; Deschamps et al., 2012; Camoin and Webster, 2014), even if uncertainties concerning the general pattern of the last deglacial sea-level rise remain. Concerning isolated carbonate platforms where corals represent the main carbonate producers, reefs have the potential to develop different geometrical expression (aggrading vs retrograding reefs) depending on the timing and amplitude of sea-level change (Kendall and Schlager, 1981). In this context, it is known that reefs may respond quickly to a flooding, through:1) the formation of reef flat and pinnacles on platform tops (Camoin et al., 2012), 2) the preservation of antecedent glacial topographies in the reef pattern (Droxler and Jorry, 2013), and 3) the accumulation of calciturbidites in adjacent basins (Droxler and Schlager, 1985; Schlager et al., 1994) immediately (less than $1 \mathrm{ka}$ ) after the flooding of the platform top (Jorry et al., 2008, 2011).

This paper aims to document the geomorphology and the sedimentology of three isolated carbonate platforms located in the Mozambique Channel, SW Indian Ocean. These islands offer unique conditions related to a sustained reef activity typified by the production of carbonate sands and the occurrence of fossil reefs, including exposed reef terraces from the last interglacial, and successive submerged reef flats formed during the last deglaciation. We propose to compare the geomorphological impact and inheritage of both glacial terminations on the edification of these islands, distributed along a $11^{\circ}$ latitudinal trend. This study also contributes to document the sedimentology of rare examples of modern isolated carbonate platforms in the SW Indian Ocean.

\section{Study area}

Within the geodynamic evolution of the Gondwana break up, the study area has recorded extensive volcanism onshore Madagascar with a large trap during Turonian times (Storey et al., 1995) and volcanic episodes associated with the reactivation of ancient structures during the Paleogene (Rasamimanana et al., 1998). The late Jurassic ocean crust (Tithonian 150 Ma; Müller et al., 2008) in the Somali/Comores Basin and Mozambique Basin was penetrated by extrusive volcanic edifices from the early Cenozoic to modern times (Bardintzeff et al., 2010; Class et al., 1998; Emerick and Duncan, 1982). The volcanic edifices crop out in the Comoro Islands, including Mayotte, the Geyser and Zélée banks, and the Glorieuses archipelago in the Comoro Sea, and Juan de Nova, Europa and Bassas da India islands in the Mozambique Channel.

The Mozambique Channel exhibits a highly contrasted ocean sedimentation. The best known sedimentary system is the Zambezi turbiditic canyon (Kolla et al., 1980; Droz and Mougenot, 1987), where large quantities of sediments have been exported from the Zambezi drainage basin since the Oligocene; this system has also contributed to the formation of a large continental shelf along the Mozambique margin. Eastward, the Madagascar margin is characterized by a sharp continental shelf and an abrupt continental slope cut by numerous canyons. Despite the important fluxes of terrigenous sediment dumped into the Mozambique Channel, several isolated scattered carbonate platforms rest on seamounts rising steeply from the seabed located at $3000 \mathrm{~m}$ water depth, i.e. the Iles Eparses.

The Iles Eparses are small and flat coral platforms located in SW Indian Ocean (Fig. 1) and include: Europa, Bassas da India, Juan de Nova, Glorieuses, and Tromelin. The Iles Eparses form the 5th district of the French Southern and Antarctic Lands since February 2007. They cover a total of 44 sq.km with a highest elevation which does not exceed a few meters. Located at low latitudes (between $22^{\circ} \mathrm{S}$ for the Europa island and $11^{\circ} \mathrm{S}$ for the Glorieuses archipelago), the Iles Eparses are exposed to a tropical climate located on cyclone trajectories coming from the northeast. The climate of the area is tropical with a mean sea-surface temperature ranging from $29^{\circ} \mathrm{C}$ in January to $22{ }^{\circ} \mathrm{C}$ in September. It receives $\sim 1010 \mathrm{~mm}$ of rainfall annually. Daily waves are influenced by the trade winds, which blow from the east between March and December and from the north-east between January and February. The tidal range is ca $3 \mathrm{~m}$.

\section{Previous studies of the Iles Eparses}

Very few studies concerning the geology of the Iles Eparses have been carried out. The outer slopes of the carbonate platforms are extremely steep $\left(20-35^{\circ}\right)$, suggesting that a volcanic basement acted as a substratum for coral growth (Battistini and Cremers, 1972; Maugé et al., 1982). However, the lack of volcanic rock outcrops and the unknown depth of the basement beneath the platform make uncertain the interpretation of the nature of the substratum beneath reef deposits. Maugé et al. (1982) have reported the presence of a submarine structure on the northern flanks of the Glorieuses edifice interpreted as a secondary volcanic edifice along the flank of the main volcano.

Knowledge regarding the sedimentation pattern of the Iles Eparses relies exclusively on a single study conducted at Glorieuses by Battistini et al. (1976a). This study concluded that 1 - the sedimentation of the archipelago is dominated by biogenic carbonates, 2- the sediment distribution on the submarine plateau of Glorieuses depends on morphology and streams, 3- from the microfaunic study, only a few planktonic foraminifers have been observed, but benthic foraminifers and bryozoans are abundant, the latter ones being seemingly specific of Indo-Malaysian areas, 4the sediment grain size distribution in the Glorieuses seems to be related to the hydraulic regime of the archipelago.

The first dating results of the fossil reefs were obtained by Battistini et al. (1976a, 1976b) in the Glorieuses, using the ${ }^{230} \mathrm{Th} /{ }^{234} \mathrm{U}$ method. Fossil coral reefs from Grande Glorieuse are dated at 150,000 $\pm 20,000 \mathrm{yr}$ BP (Before Present), and at about $159,000 \pm 20,000 \mathrm{BP}$ for Ile du Lys. More recent Th/U dates provided by Gaven and Vernier (1979) for corals taken from the same outcrops ranged between 99,000 and 108,000 yrs BP. Based on the discrepancy with the previously reported ages and on assumed sealevel changes around the last interglacial period (Marine Isotope Stage [MIS] 5e), the occurrence of a depositional unconformity at $\sim 125,000 \mathrm{yr}$ BP due to reef drowning and an average uplift rate of $0.2 \mathrm{~mm} \mathrm{yr}^{-1}$ since $\sim 130,000 \mathrm{yr}$ BP were deduced. More recently, new dating results obtained on fossil reef terraces of the Glorieuses Islands have confirmed that these reefs developed exclusively during the first MIS5e sea-level highstand (Guillaume et al., 2012).

\section{Materials and methods}

The REEFCORES (REEFs and CORals from the EparseS) program is dedicated to the sedimentological study of the Iles Eparses, by studying the distribution of carbonate sands and fossil reefs. Samples were collected mainly on leeward sides of all the Iles Eparses in April 2011 during a multidisciplinary research cruise coordinated by the French Southern and Antarctic Lands onboard the RV Marion Dufresne. Sediments were collected using a dredge from a small boat which has been unloaded/loaded each day from the RV Marion Dufresne. A second expedition was completed in 2013 onboard the Antsiva vessel allowed to complete the sampling of sediments and rocks and to acquire seismic data in the Glorieuses archipelago. A total of 125 sediment samples have been collected from intertidal to subtidal (up to $35 \mathrm{~m}$ of water depth) in the Glorieuses, 66 samples in Juan de Nova, and 40 samples in Europa. $176 \mathrm{~km}$ of seismic profiles have been acquired in the Glorieuses in 2013. 


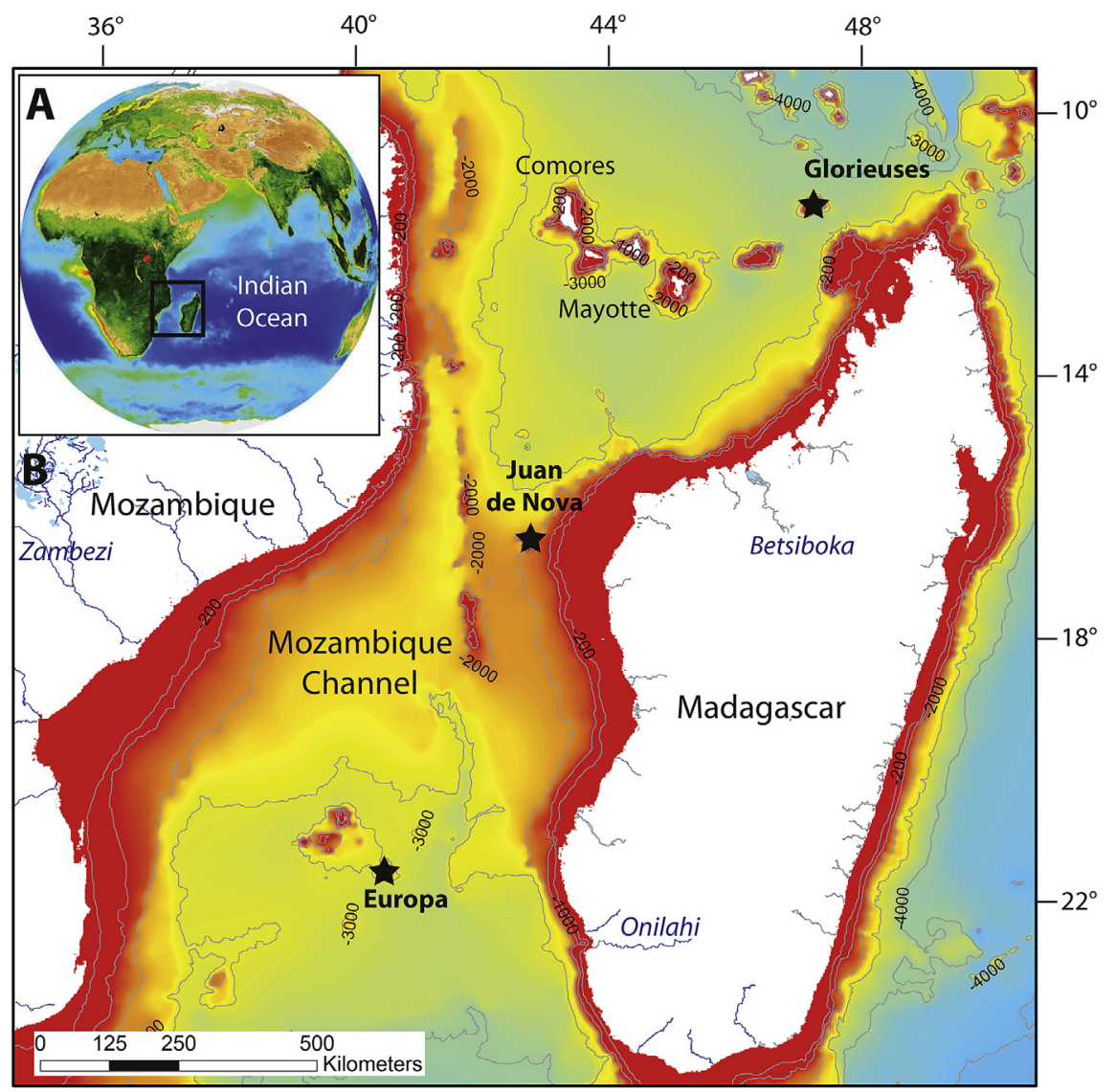

Fig. 1. Location of the Glorieuses archipelago, Juan de Nova and Europa platforms in the SW Indian Ocean

Each sediment sample was sub-sampled and wet sieved. The following size fractions were sieved: $<2 \mathrm{~mm},>2 \mathrm{~mm},>4 \mathrm{~mm}$, $>8 \mathrm{~mm}$ and $>16 \mathrm{~mm}$. Carbonate components from the $<2 \mathrm{~mm}$ fraction were counted ( 300 points per sample) under binocular using a point counter. The fine fractions $(<63 \mu \mathrm{m})$ were subsequently investigated under SEM.

Multivariate statistical methods (cluster and principal component analyses) were performed on sediment collected at Iles Eparses. Cluster analysis has been run only for sediments collected at Glorieuses. Fractions between $250 \mu \mathrm{m}$ and $2 \mathrm{~mm}$ were used to quantify components. Due to the absence of carbonate mud, grains $<125 \mu \mathrm{m}$ were considered as matrix/"mud". Facies were defined according the Dunham (1962) classification.

To perform high resolution seismic, a Sparker Source, a singlechannel SIG streamer and a numerical DELPH acquisition system were used at Glorieuses. The sparker emission energy ranges from 25 to $160 \mathrm{~J}$, the shooting rate was $250 \mathrm{~ms}$ and the vessel bottom speed was $4-5$ knots. The signal penetration gives satisfaction in lagoonal sediments. Although, the attenuation of the high resolution signal is important beneath the high amplitude reflectors corresponding to reefal substrates and amplifies the seabed multiple reflector by shallow water. These limitations prevent the examination of inner reefal structures and the lower part of seismic records. Raw data have been processed using Delph Interpretation (developed by ix Blue). Interpretation of seismic lines was conducted using Kingdom Suite software (Seismic micro technology INC). Seismic lines are displayed with two-way travel time in ms. Time-depth conversions have been made assuming an average velocity of $1800 \mathrm{~m} / \mathrm{s}$ for unconsolidated sediments.

Furthermore, laser bathymetry and topography (LiDAR) were available through the area. The acquisition has been made between 2009 and 2011 and conducted by the French Institut Geographique National (IGN) and Service Hydrographique et Oceanographique de la Marine (SHOM). They allowed metric accuracy on the plane and decimetric precision of heights and depths.

\section{Results}

\subsection{Geomorphology and modern environments of the Iles Eparses}

\subsubsection{A- Glorieuses}

The Glorieuses archipelago may be considered a sentinel at the entry of the Mozambique Channel (Fig. 1). The archipelago is a group of islands and rocks of $5 \mathrm{sq}$. km, about $160 \mathrm{~km}$ northwest of Madagascar. The archipelago consists of two main islands, Grande Glorieuses and île du Lys, as well as eight rock islets. Grande Glorieuses is roughly circular, about $3 \mathrm{~km}$ across (Fig. 2A). It is densely vegetated, mainly by the remains of a coconut plantation and casuarina trees. Ile du Lys (Fig. 4A), located at about $8 \mathrm{~km}$ northeast of Grande Glorieuse, is about $600 \mathrm{~m}$ long and consists of sand dunes and scrub with some mangroves. It was formerly quarried for phosphate (guano).

The energy regime in the Glorieuses is influenced by E/SE dominant trade winds, and NO monsoon winds occur between December and February (Fig. 3A). The regime of trade winds may explain the general configuration of the archipalego, with a barrier reef developed along a SE windward side and a leeward inner platform located further north (Figs. 2B and 4A).

The Glorieuses archipelago can be subdivided into several geomorphological areas (Fig. 2B): the islands, the forereef, the reef 

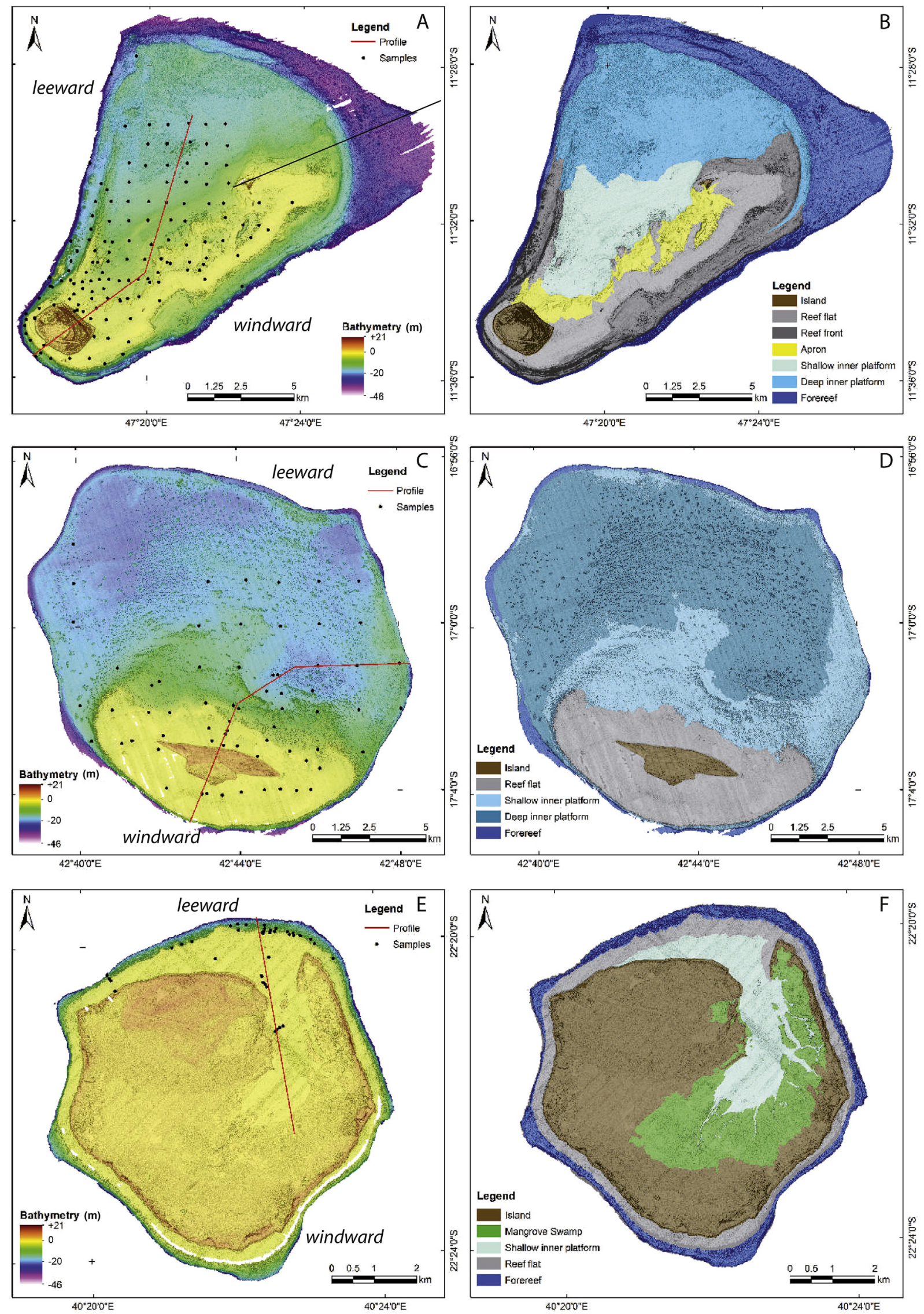

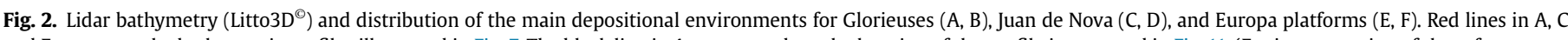

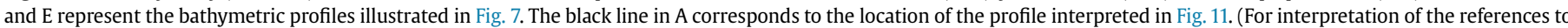
colour in this figure legend, the reader is referred to the web version of this article.) 

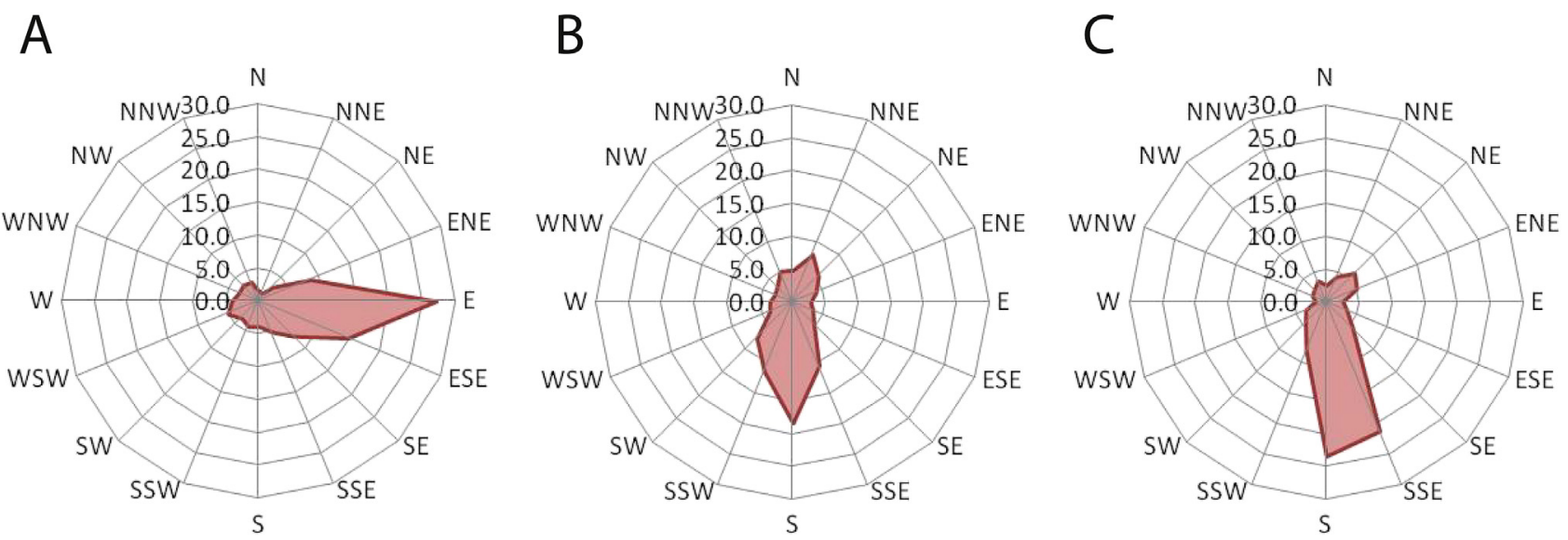

Fig. 3. Annual wind statistics for Glorieuses (A), Juan de Nova (B), and Europa (C). Source of the dataset available on www.windfinder.com.

flat, the apron, and the inner platform which can be subdivided into a shallow and a deep region. Grande Glorieuse island is formed by the accretion of beach ridges and aeolian sand dunes built by dominant eastward trade winds. The largest littoral dune field is developed along the north-eastern part of the island. Sand beaches are composed of wave ripples associated with transverse tidal ripples (Fig. 4B). With a mean water depth of $6 \mathrm{~m}$, the bathymetry of the inner platform (Figs. 2A and 4B) increases rapidly northwards (up to $25 \mathrm{~m}$ ). A sandwave field is $500-600 \mathrm{~m}$ wide and $4 \mathrm{~km}$ long, forming a $3 \mathrm{~m}$ high apron displaying a SW-NE orientation (Figs. 2B and 4A). Elongated sandwaves with crests emerging at low tide (Fig. 4C) and numerous pinnacles are developed within the inner platform. Beaches are often affected by an intense bioturbation activity, in particular due to crabs (Fig. 4D). Some beachrocks are found at the southern tip of Grande Glorieuse island (Fig. 4E), which are sometimes covered by washover deposits (Fig. 4F). The deepest parts of the inner platform $(-10$ to $-25 \mathrm{~m})$ are located in the northern part of the archipelago and are composed of a rough seafloor made of pinnacles up to $6 \mathrm{~m}$ high, and coral fragments (Fig. 4G).

The reef flat emerging at low tide forms a continuous, flat SW-NE reef trend extending over $16 \mathrm{~km}$ (Figs. 2B and 4A). The internal part of the reef flat shows some depressions with water depths ranging from 3 to $8 \mathrm{~m}$ (Fig. 4A). The forereef is developed between 5 and $20 \mathrm{~m}$ water depth (Figs. $2 \mathrm{~B}$ and $4 \mathrm{~A}$ ). It is represented by a coarse coral sand formed by the dismantling of the modern reef. Between -12 and $-40 \mathrm{~m}$ deep, the forereef exhibits a succession of submerged flat reef terraces, forming ancient reef flat at $-16 \mathrm{~m},-19 \mathrm{~m},-25 \mathrm{~m}$, and $-40 \mathrm{~m}$ deep. These submerged terraces are mainly developed at the north-eastern tip of the archipelago (Fig. 2A).

Several rock units made of meter-sized fossil reefs crop out in the eastern part of the Grande Glorieuse island. Compared to Grande Glorieuse, Ile du Lys is exclusively made of beachrocks and fossil reefs, partly karstified (Fig. 4A). The south and south-western part of this island is covered by modern carbonate sands associated to guano. The highest outcrops, up to $5 \mathrm{~m}$ high, are located on the north-eastern part of the island. A small depression is located at the center of island, allowing the development of a laguna which interacts during high tides with the inner platform. Other exposed fossil reefs are distributed along the modern reef flat in the Roches Vertes and Ile aux Crabes areas. These elevated reef terraces occur 3-5 $\mathrm{m}$ above the modern mean sea level, and are strongly karstified.

\subsubsection{B- Juan de Nova}

Juan de Nova is located at $600 \mathrm{~km}$ south of Mayotte, $280 \mathrm{~km}$ off the African coast and $175 \mathrm{~km}$ from the west coast of Madagascar
(Fig. 1). The cool season at Juan de Nova ranges from April to November. During this period, rainfall is very low, average temperatures range from $28.4{ }^{\circ} \mathrm{C}$ (April) to $25{ }^{\circ} \mathrm{C}$ (August) and the prevailing winds blow from the south to southwest (Fig. $3 \mathrm{~B}$ ). The rainy season occurs from December to March. At that time, the average temperatures vary little $\left(28.4{ }^{\circ} \mathrm{C}-28.5{ }^{\circ} \mathrm{C}\right)$ and precipitations are spread over the same period from $100.7 \mathrm{~mm}$ to $275.8 \mathrm{~mm}$.

The emerged land covers 4.4 sq.km (Fig. 2C). The main geomorphological areas are represented by an island, a reef flat and an inner platform (Figs. 2D and 5A). A large crescent barrier reef and a reef flat are developed along the southern windward side (Figs. 2D and 5A), while a shallow (up to $5 \mathrm{~m}$ water depth) and a deeper (up to $25 \mathrm{~m}$ water depth) inner platform occur on the leeward side (Figs. 2D and 5A). Numerous sand bars and pinnacle reefs develop on the shallow inner platform. The deep inner platform is mostly represented by enclosed intra-platform basins (Fig. 2C, dark blue areas) edged by pinnacle reefs, where fine sands accumulate.

Similar to Glorieuses, the intertidal zone is characterized by the presence of sandy tidal sand flat exposed at low tide, showing some tide and wave-induced current ripples (Fig. 5B). This tidal flat is partly affected by strong waves and storms which induce spillovers (i.e. reworking of coarse sands) in intertidal and supratidal zones (Fig. 5C). Sand bars developed at leeward side (in the shallow inner platform) are elongated northwards, with crests emerged at low tide (Fig. 5A).

The island consists of beachrocks (Fig. 5D), sand dunes up to $12 \mathrm{~m}$-high, and fossil reefs which display a maximum elevation of $5 \mathrm{~m}$ above modern sea level (Fig. 5E). The fossil reefs are composed of nicely preserved fossil corals and of abundant giant bivalve shells (Tridacna sp.) in living position; they are capped by cemented stratified deposits, which could be interpreted as preserved foreshore or washover deposits from the last interglacial period (125000 years ago).

\subsubsection{C- Europa}

Europa is located at $600 \mathrm{~km}$ south of Juan de Nova (Fig. 1) and represents the largest emerged area (30 sq.km) of the five Iles Eparses (Figs. 2E and 6A). Climate is affected by the Agulhas Current with water temperatures usually above $30^{\circ} \mathrm{C}$. The energy regime of the area is influenced by S-SE trade winds (Fig. 3C) occurring during the (austral) winter and by occasional cyclones.

Europa is $6 \mathrm{~km}$ in diameter, with a maximum altitude of $6 \mathrm{~m}$, and has $22.2 \mathrm{~km}$ of coastline. It is surrounded by coral beaches, a fringing reef, and encloses a mangrove lagoon of around $9 \mathrm{sq} . \mathrm{km}$ 

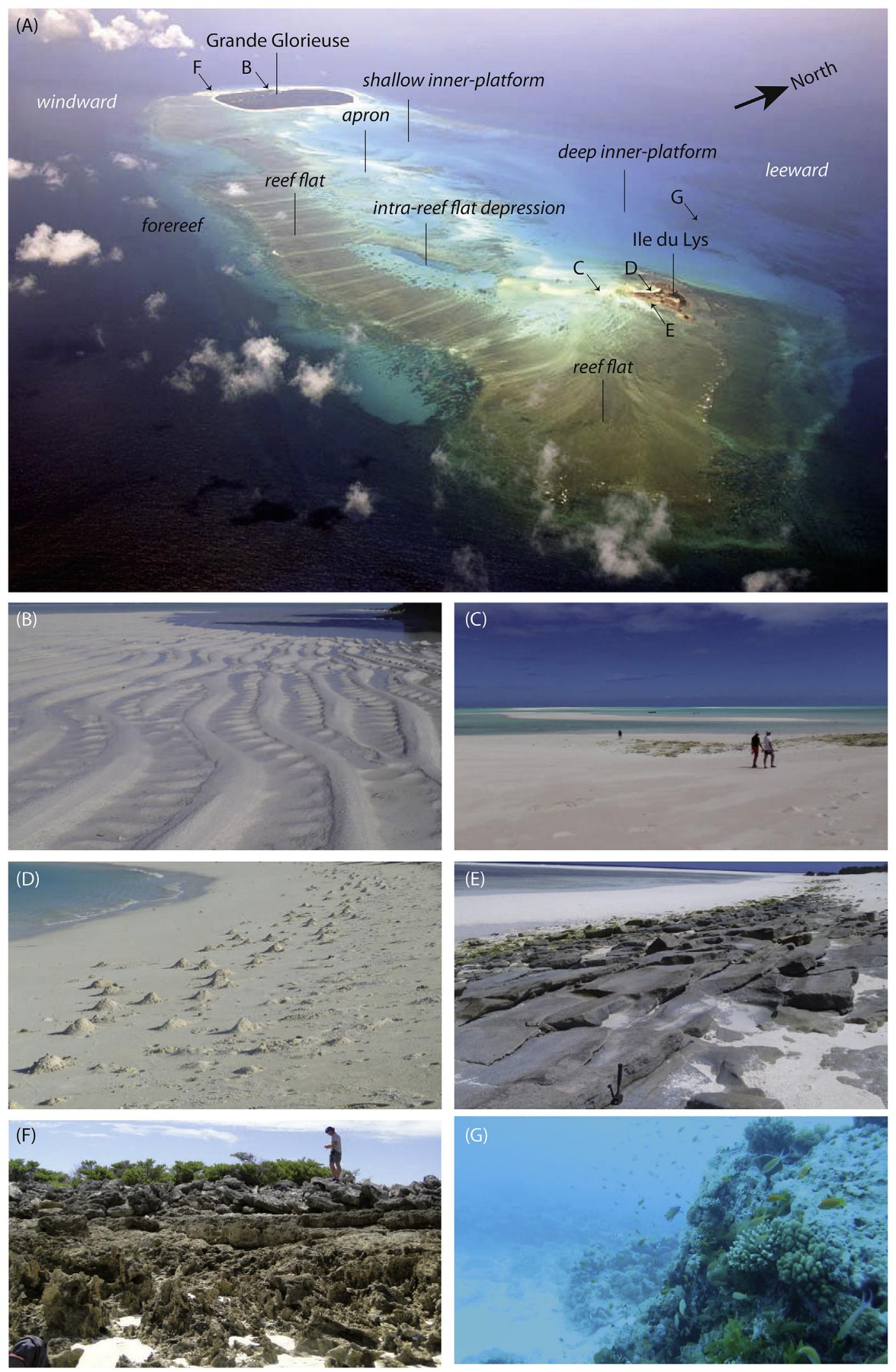

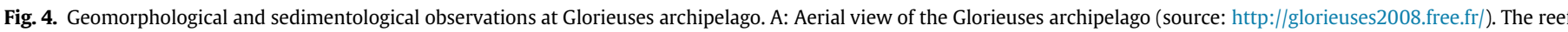

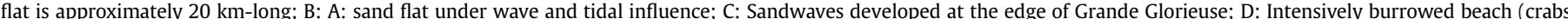

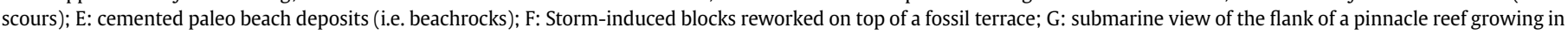
the deep inner-platform. Approximate locations of photograph B, C, D, E, F, G are indicated on the aerial view (A). 

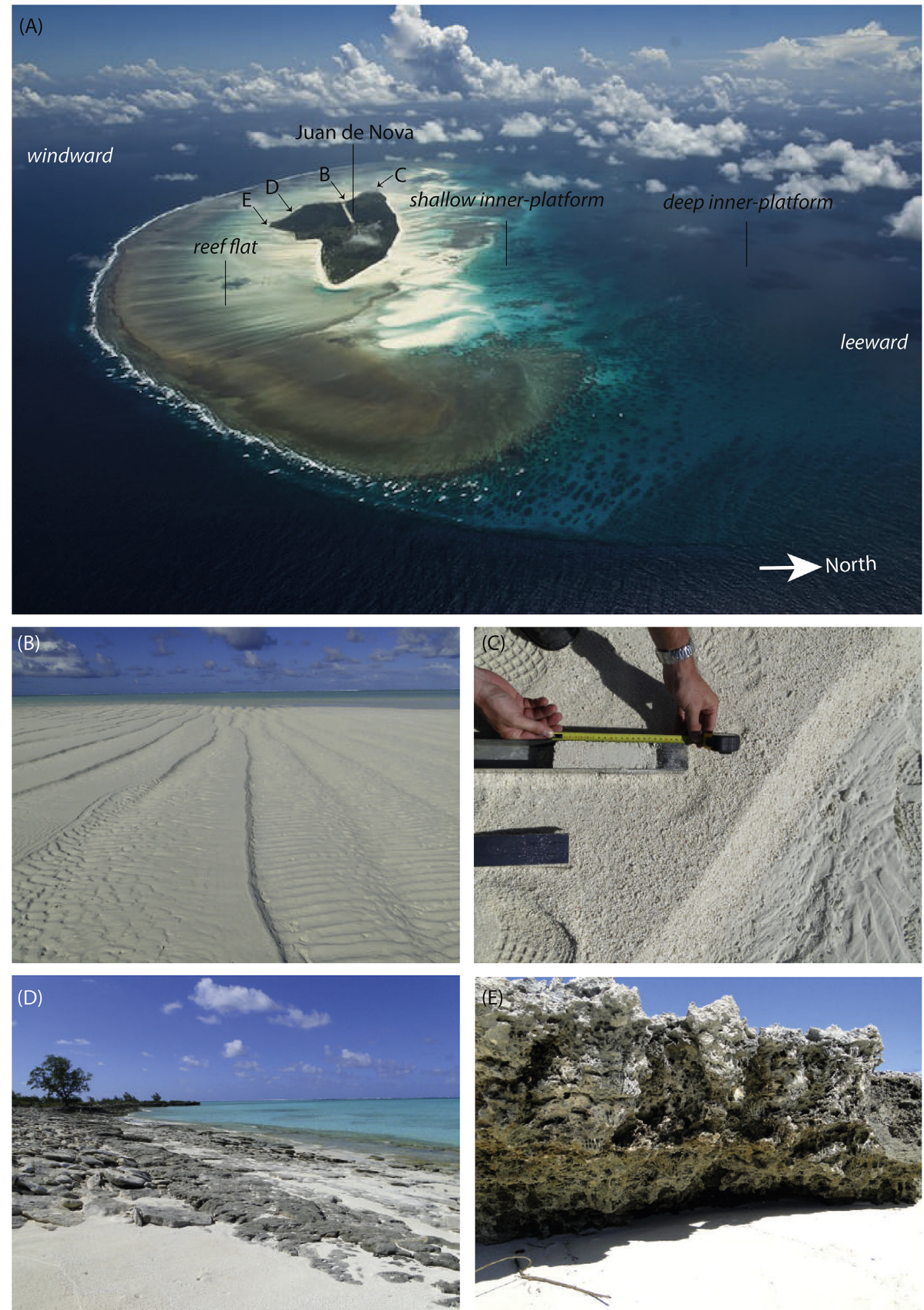

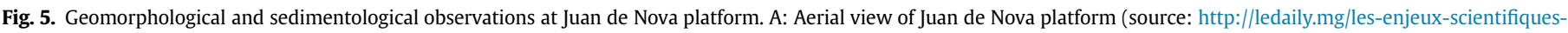

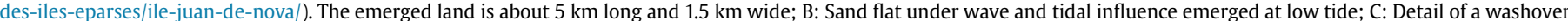

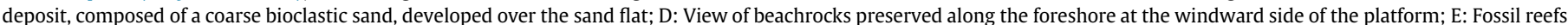
(around $3 \mathrm{~m}$ high) composed of fossil coral preserved in living position. Approximate locations of photograph B, C, D, E are indicated on the aerial view (A).

(Figs. 2F and 6B). Its vegetation consists of dry forest, scrub, spurge, the mangrove swamp, and the remains of a sisal plantation. It is one of the world's largest nesting sites for green sea turtles (Bourjea et al., 2008).
The surrounding reef is more developed on the windward side (i.e. southern) of the island, while it is submerged on its northern side (Fig. 6A). A shallow internal lagoon occurs in the north-east part of the island and covers $1 / 5$ of the total surface of the island 

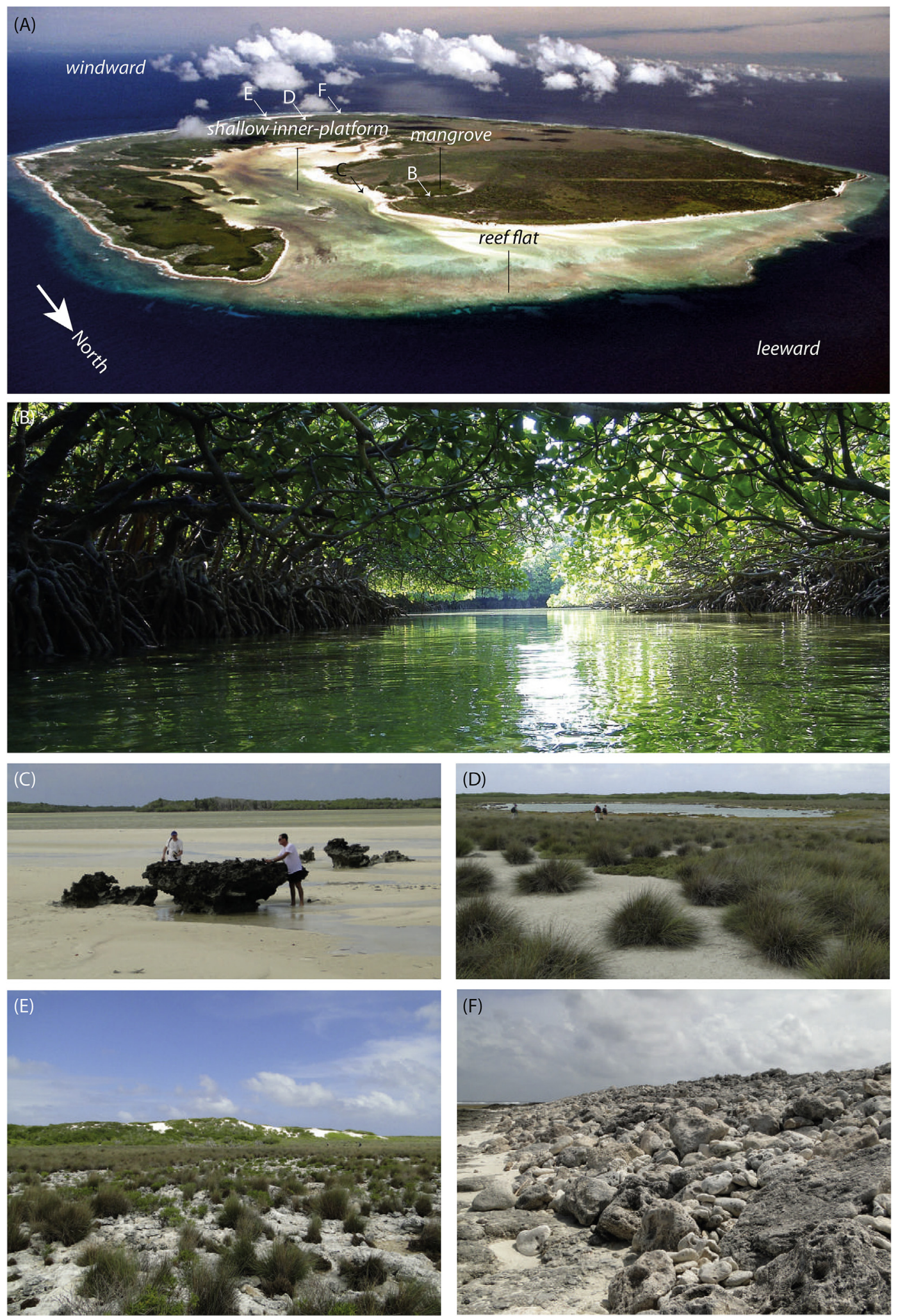

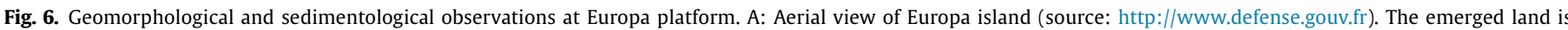

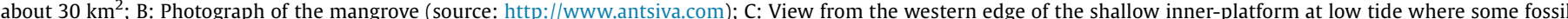

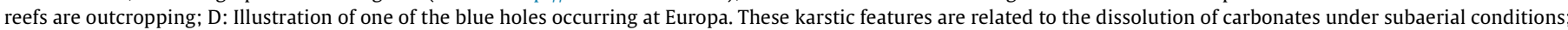

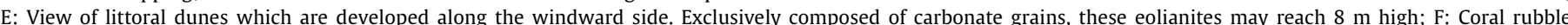

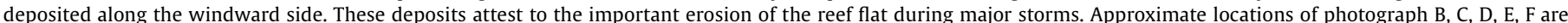
indicated on the aerial view (A). 
(Figs. 2F and 6A). Some fossil reefs are observed along the edges of the inner platform (Fig. 6C). They are represented by meter-scale fossil patch reefs composed of nicely preserved branching and massive corals. Several depressions (2 $\mathrm{m}$ deep on average) are distinctive features (Fig. 6D: "blue holes") in the interior of the island and are interpreted as karstic cavities, resulting from the dissolution of ancient reef structures due to freshwater flow.

The windward side in Europa is somewhat specific compared to the two other islands. In front of the blue holes, a large field of littoral dunes developed along the windward side (Fig. 6E). These dunes, up to $8 \mathrm{~m}$ high, are exclusively composed of carbonate sands. At the foot of the dunes, carbonate breccias are deposited (Fig. 6F); they breccia are comprised of meter-sized blocks of coral heads extracted from the barrier reef during exceptional storm events. At some places, these blocks are cemented by coarse sands forming outcrops of $2-3 \mathrm{~m}$ in height.

\subsection{Composition and distribution of carbonate sands}

\subsubsection{A- Glorieuses}

The distribution of carbonate components has been quantified at Glorieuses (Fig. 7A). By order of abundance, medium to coarse sands are dominated by coral fragments, green algae (Halimeda), benthic foraminifers and mollusc shells. Grain sizes $<2 \mathrm{~mm}$ represent about $80 \%$ of the total samples (Fig. 8), with large quantities of Halimeda and fragments of large benthic foraminifers. All samples collected over the archipalego show the absence of carbonate mud $(<63 \mu \mathrm{m})$ and of non-skeletal grains such as ooids. Preliminary SEM observations show that fines are composed of small $(<63 \mu \mathrm{m})$ bioclasts.

Coral fragments are mostly abundant in high-energy zones bordering the windward margin, i.e. the reef front and the reef flat, where these particles reach $18 \%$ on average of the total composition of the sediment (Fig. 7A). Coral fragments are also present in the deep inner platform where many pinnacles occur. Halimeda represent more than $20 \%$ of the total composition of sediments all over the archipelago, and reach up to $60 \%$ at some localities in the inner platform (Fig. 7A). Large benthic foraminifers are mainly abundant on the reef flat. They represent also about $50 \%$ of the total grain composition of sand dunes deposited along the apron (Fig. 4A, $\mathrm{C}$ ), in the shallow inner platform (Fig. 7A). Concerning molluscs, their highest abundance is recorded in the deeper parts of the inner platform.

\subsubsection{B- Juan de Nova}

Juan de Nova samples display a wide range of grain sizes. Despite the dominance of the $<2 \mathrm{~mm}$ fraction, Juan de Nova shows the highest proportions of grain sizes $>2 \mathrm{~mm},>4 \mathrm{~mm},>8 \mathrm{~mm}$ and $>16 \mathrm{~mm}$ compared to Glorieuses and Europa (Fig. 8). Sizes $<2 \mathrm{~mm}$ and $>2 \mathrm{~mm}$ are present in all samples, size $>4 \mathrm{~mm}$ being present in $80 \%$ of the samples. Grain sizes $>8 \mathrm{~mm}$ and $>16 \mathrm{~mm}$ occur in $11 \%$ of the total samples. The sediment composition in the grain size fraction $<2 \mathrm{~mm}$ shows large quantities of corals (41\%). Halimeda display the largest contents with $60 \%$. The next biggest group (14\% of total grains) is represented by molluscs. Foraminifers form $5 \%$ of the grains. Echinoids, bryozoan and red algae occur in small amounts of about $1 \%$ of the grains. Carbonate mud $(<63 \mu \mathrm{m})$ and non-skeletal grains have not been identified in the grain size fraction $<2 \mathrm{~mm}$.

Similar to Glorieuses, coral fragments are mainly distributed along the reef flat, and at the edge of the deep inner platform (Fig. 7B). Halimeda are mainly distributed on the reef flat and at the north of the emerged land, where sand dunes are deposited on the leeward side. Foraminifers and molluscs are mostly abundant in the inner platform, with the highest proportion in the deeper part of the inner platform. We observe also that the coral abundance is higher eastwards and is inversely related to the abundance in foraminifers and molluscs (Fig. 7B). This trend seems to be correlated with a decreasing water depth from inner platform to the reef flat.

\subsubsection{C- Europa}

The Europa samples show a similar grain size distribution to the two other platforms, although there is a higher proportion of grains $<2 \mathrm{~mm}$ (Fig. 8). Grain sizes $<2 \mathrm{~mm}$ and $>2 \mathrm{~mm}$ are present in all samples, grain size $>4 \mathrm{~mm}$ is present in $75 \%$ of the samples. Grain sizes $>8 \mathrm{~mm}$ and $>16 \mathrm{~mm}$ represent $21 \%$ of the total amount of samples. Increasing grain size coincides with decreasing amount of grains present in each sample. Europa sediment composition is represented by three major elements: Corals are the most abundant components and represent about $50 \%$ of all investigated grains in the grain size fractions $<2 \mathrm{~mm}$ and $>2 \mathrm{~mm}$. Another important part of the grains is represented by Halimeda (almost $20 \%$ of the total composition), and molluscs (about $18 \%$ of the total amount) in the grain size fraction $<2 \mathrm{~mm}$. Foraminifers represent $7 \%$ in average of all counted grains in the grain size fraction $<2 \mathrm{~mm}$, their amount in the samples ranges between 1 and 37\%. Other components (red algae, echinoids, bryozoan, teeth, and worm tubes) occur in minor proportions, representing less than $5 \%$ of the grains in both size fractions. Similar to Glorieuses and Juan de Nova, carbonate mud and non-skeletal grains are absent in Europa.

The sediment distribution along a transect going from the inner platform to the reef front shows a rather uniform distribution of corals (Fig. 7C). In the inner platform itself, the quantities of corals vary between 55 and $85 \%$ with higher amounts southwards. Molluscs also show similar abundances in the samples along the transect, between 14 and 23\%. Foraminifers whose abundance ranges from 7 to $9 \%$, occur mostly in samples located in high energy zones close to the front reef, while they are mostly absent in the inner platform. Echinoids and red algae also occur only close to the front reef, although some individual echinoids can be found further south in the inner platform. In contrast, Halimeda grains show a rather uniform distribution from inner (protected) to outer (exposed) areas, with higher abundance noted along the reef flat and the reef front (more than $20 \%$ on average).

\section{Discussion}

\subsection{Impact of island morphology and energy regime on the distribution of carbonate grains}

Lagoonal sedimentation on the Iles Eparses is characterized by the occurrence of three main sedimentary components - corals, foraminifers and molluscs-in the investigated grain size fractions $(<2 \mathrm{~mm}$ and $>2 \mathrm{~mm}$ ); corals correspond to the most abundant component on both islands and reach higher values on Europa. The main sedimentary components include also green algae (mostly Halimeda). Other constituents such as aggregates, echinoids and red algae occur in minor quantities. Bryozoan, fish teeth, worm tubes, and carbonate rock fragments are rare. This is consistent with the results obtained by Gischler (2006) on the small carbonate system of Ari atoll and of the larger Rasdhoo platform (Maldives, Indian Ocean).

In order to study the spatial variability of all samples between our three study areas, we performed a non-standardized principal component analysis using Past software (Hammer et al., 2001) on the basis of the percentage data (corals, Halimeda, molluscs, foraminifera, echinoids, bryozoans, grain size class) and sample water depth. This multivariate analysis is based on 229 samples and 12 variables, and yields two significant axes, explaining $81 \%$ of the total variability. The eigenvalues for these two axes and the variable 
A

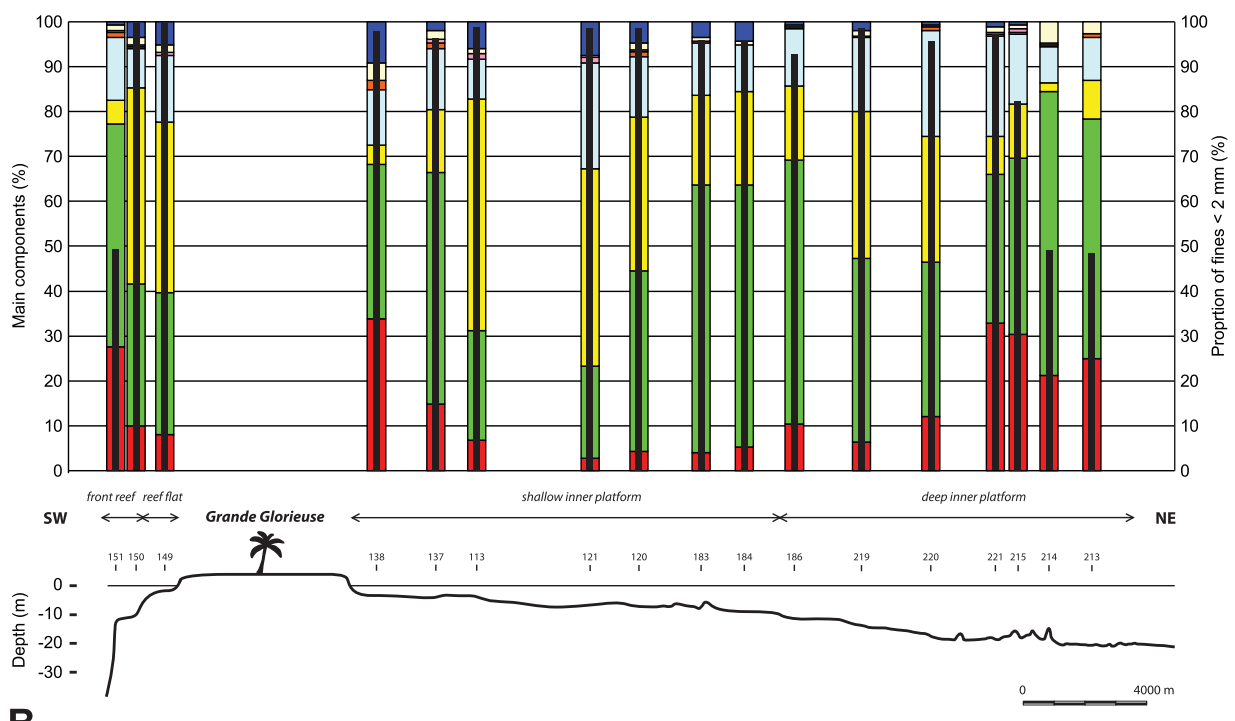

B
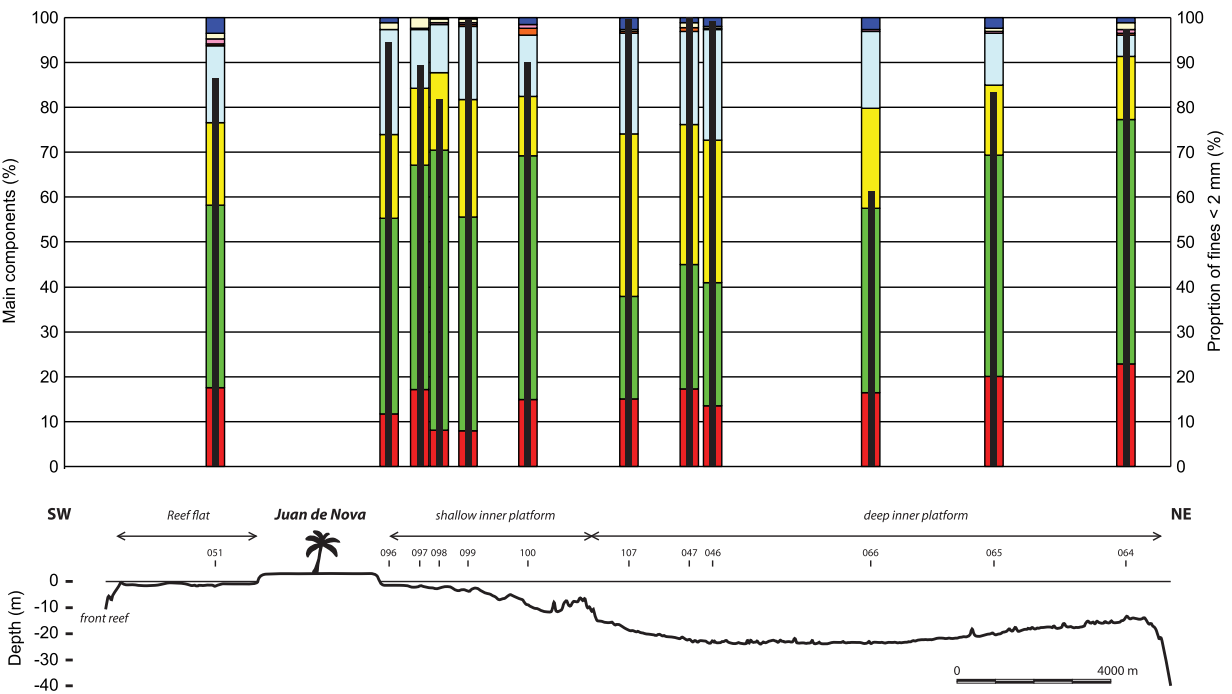

C

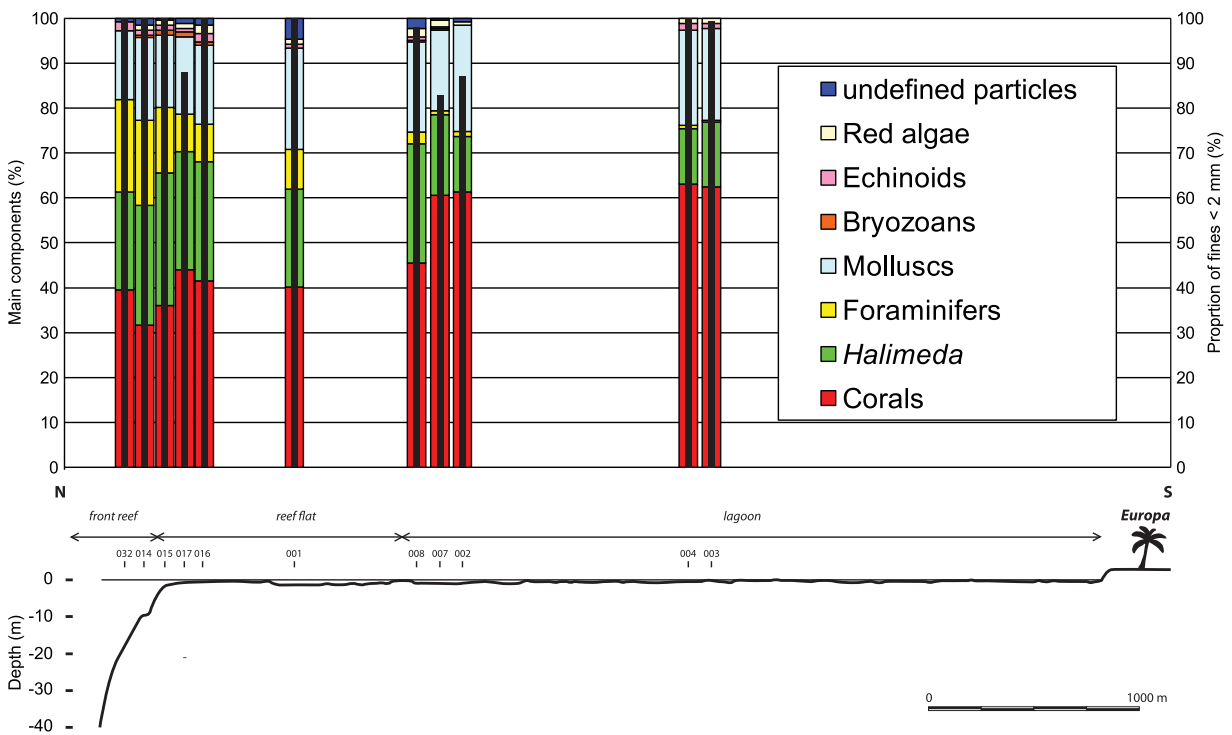

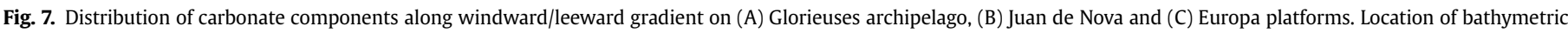
profiles are indicated on Fig. 2. Quantification of each component has been performed on the $<2 \mathrm{~mm}$ fraction. 


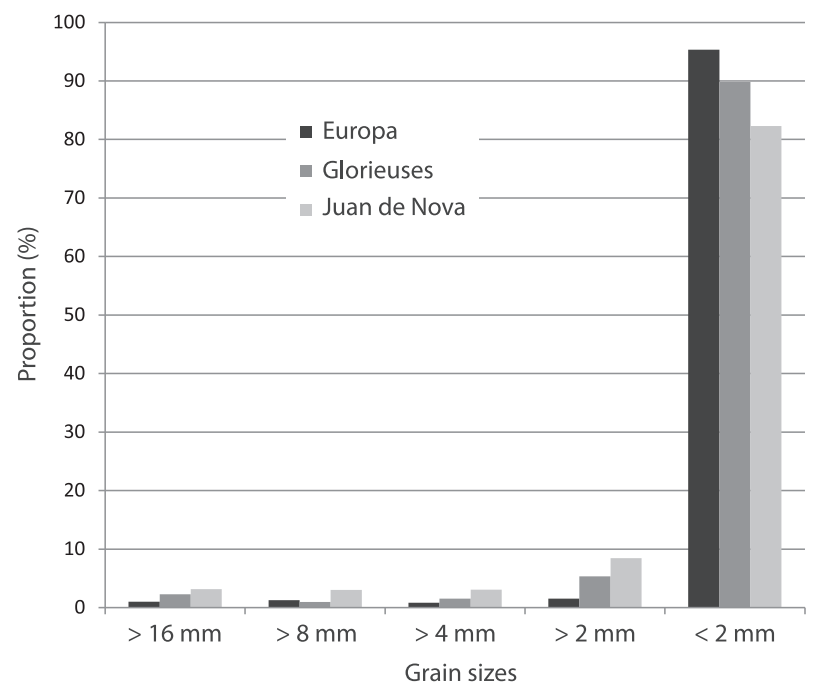

Fig. 8. Proportion of grain sizes at Glorieuses, Juan de Nova and Europa.

loadings on the axes are given in Table 1 . The positive side of axis 1 is highly dominated by Halimeda fragments (0.73), whereas corals $(-0.66)$ loads negatively on the first axis. The positive side of the second axis is dominated by particles larger than $2 \mathrm{~mm}(0.32)$ and coral fragments contribution (0.30) while relatively fine particles $(<2 \mathrm{~mm})(-0.80)$ and foraminifera $(-0.30)$ load negatively. Fig. 9 shows the position of the 229 samples gathered in the three study area in the axial plot. The first axis allows a clear separation between samples gathered in Europa (rich in corals fragment) from samples collected at both Juan de Nova and Glorieuses (rich in Halimeda). The second axis suggest that samples from Glorieuses present a relatively stronger contribution of fine particles $(<2 \mathrm{~mm})$ rich in foraminifera compared to Juan de Nova where coarser sediments (between 2 and $4 \mathrm{~mm}$ ) are dominant.

Cluster analysis based on the sediment database from Glorieuses confirms the study made on the distribution of carbonate grains. Composition of facies is dominated by Halimeda, grainstones composed of Halimeda and coral fragments are mostly deposited along the windward margin and close to pinnacles in the inner platform, and packstones dominated by Halimeda and foraminifers are mainly deposited in the inner platform (Fig. 10). This suggests also that the facies distribution over the archipelago is mostly

Table 1

Results of principal component analysis (trace and variable loadings) based on the percentage data (coral, Halimeda, molluscs, foraminifera, echinoids, bryozoan, grain size classes) and samples water depth.

\begin{tabular}{lrr}
\hline & PCA 1 & PCA 2 \\
\hline \% of trace & 52.76 & 28.68 \\
Cumulative percent of trace & 52.76 & 81.44 \\
Variables & & \\
Water depth (m) & 0.04 & 0.04 \\
Particle proportion (\%) $>16 \mathrm{~mm}$ & 0.03 & 0.19 \\
Particle proportion (\%) $>8 \mathrm{~mm}$ & 0.01 & 0.15 \\
Particle proportion (\%) $>4 \mathrm{~mm}$ & 0.02 & 0.15 \\
Particle proportion (\%) $>2 \mathrm{~mm}$ & 0.08 & $\mathbf{0 . 3 2}$ \\
Particle proportion (\%) $<2 \mathrm{~mm}$ & -0.14 & $\mathbf{0 . 8 0}$ \\
Corals (\%) & $-\mathbf{0 . 6 6}$ & $\mathbf{0 . 3 0}$ \\
Halimeda (\%) & $\mathbf{0 . 7 3}$ & 0.06 \\
Molluscs (\%) & -0.07 & -0.05 \\
Foraminifera (\%) & 0.01 & $\mathbf{0 . 2 7}$ \\
Echinoids (\%) & -0.01 & -0.03 \\
Bryozoans (\%) & 0.00 & -0.01 \\
\hline
\end{tabular}

Variables with significant PCA loadings are indicated in bold. controlled by the energy regime, grainstones being mostly deposited along the high energy zones (e.g. reef flat) while packstones dominate in more protected settings, e.g. the inner platform (Fig. 10).

The shallow back reef area and lagoon from Europa (intertidal zone) display a single terrace displaying homogeneous depth, creating a high-energy zone in the rims. The back reef area at Europa may be interpreted as the leeward channel not offering a reef rim for waves to break on. The very nature of a relatively shallow water sedimentary deposit would definitively dissipate wave energy into the reef environment. This may explain the lowest proportion of the green algae Halimeda compared to the other islands, which grows preferentially in shallow quiet water environments. This alga is an efficient carbonate grain producer and typically provides flat, "heart"-shaped segments which become detached when the plant dies. These segments are very light and consist of intertwined aragonite needles, displaying high porosity values. This, as well as the flat shape makes the segments easily transportable, even by weak currents and wave energy. This ability of carbonate grains to be easily reworked and transported by weak currents has been also demonstrated for large benthic foraminifers, which can be transported far away from their biotope (Yamano et al., 2000; Jorry et al., 2006). The lower abundance of Halimeda at Europa could be explained either by its lack of growth or deposition in high energy areas. Corals derive from shallow production sites such as barrier reefs, patch reefs and reef frameworks. The strong wave and current energy on Europa, due to its location at the centre of the Mozambique Channel, a region under the influence of tropical cyclones, is able to transport a relatively large amount of coral fragments compared to the other islands. Molluscs show a clear distribution in protected zones (back reef environments) at Glorieuses, Juan de Nova, and Europa. According to Gischler (2006), molluscs display the highest contents in deeper waters in Maldivian atolls. Foraminifers occur preferentially in areas with minimal influence of strong currents and wave energy, which are in the case of the shallow/deep inner platform at Glorieuses and Juan de Nova, in agreement with Gischler's (2006) observations in the Maldivian atolls. However, foraminifers appear also abundant along reef flat and talus. This might be explain by a specific type of large benthic foraminifers which are exclusively subordinate to high-energy settings, such as Neorotalia sp. (Hohenegger et al., 1998; Hottinger et al., 1991; Parker and Gischler, 2011).

The absence of carbonate mud $(<63 \mu \mathrm{m})$ in Glorieuses, Juan de Nova and Europa may be explained by transport and winnowing of fine particles by tidal and wave currents which contribute to carry suspended sediments off the platform. Water depth $(10-15 \mathrm{~m}$ on average) of the platform interiors at Glorieuses and Juan de Nova does not allow tides to supply highly supersaturated waters rich in dissolved oxygen. This parameter could explain the absence of nonskeletal grains in both areas. This sedimentological model contradicts with platforms such as the Bahamas, which are known as areas with elevated alkalinity (Lee et al., 2006) and aragonite saturation states (Gledhill et al., 2008). In addition to very shallow platform interiors, the genesis of ooids, peloids, and marine cements in the Bahamas allow water exchanges and facilitate favorable conditions for calcium carbonate precipitation (Rankey and Reeder, 2011).

\subsection{Past sea level imprints}

Zinke et al. (2003) and Camoin et al. (2004) have correlated terraces on several islands to the history of last deglacial sea-level change in the western Indian Ocean. Considering regional subsidence rates ranging from 0.13 to $0.25 \mathrm{~mm} \mathrm{yr}^{-1}$ (Camoin et al., 2004), they both related the Younger Dryas event $(12,700-11,600 \mathrm{ka})$ to a 


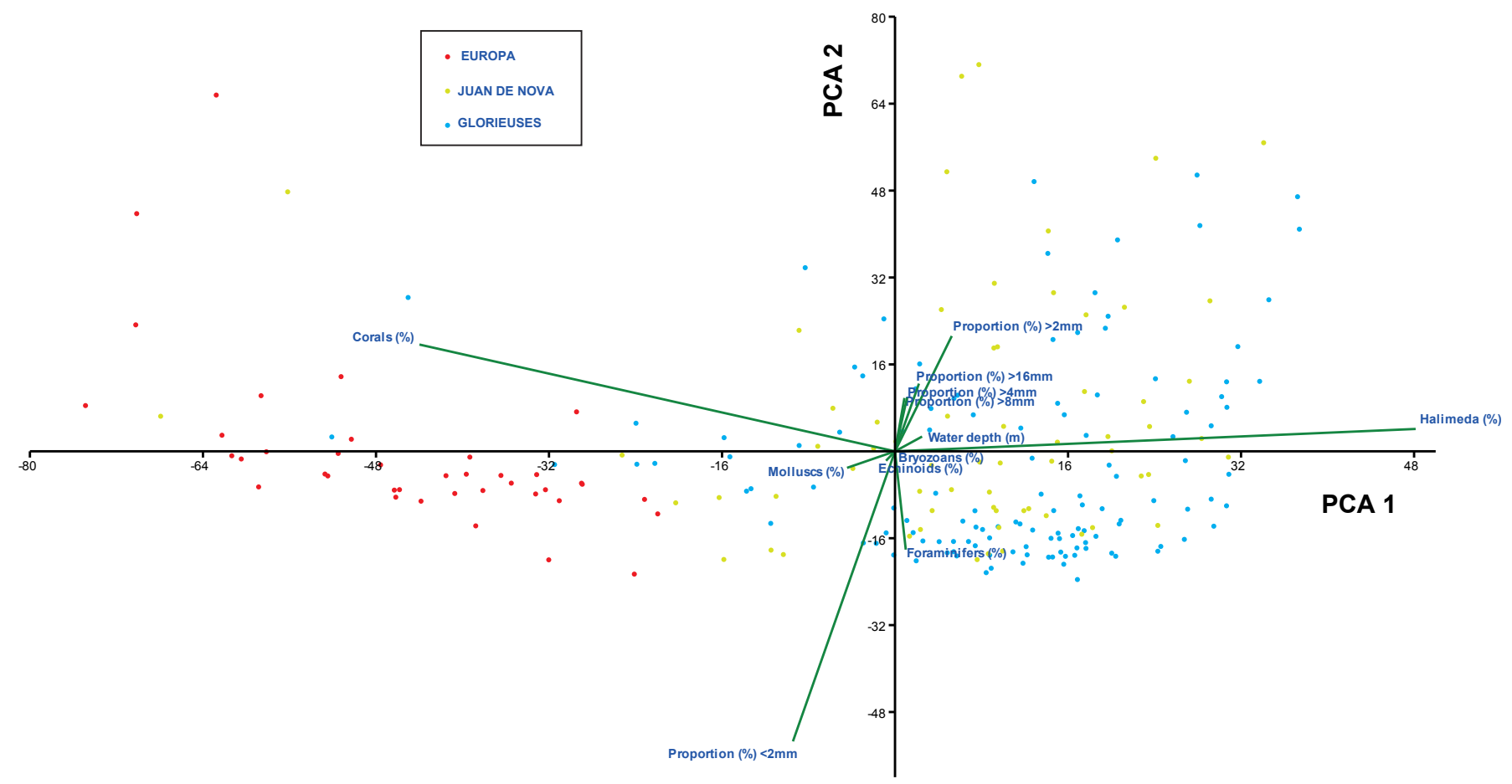

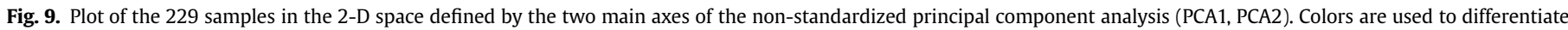
the three study areas. (For interpretation of the references to colour in this figure legend, the reader is referred to the web version of this article.)

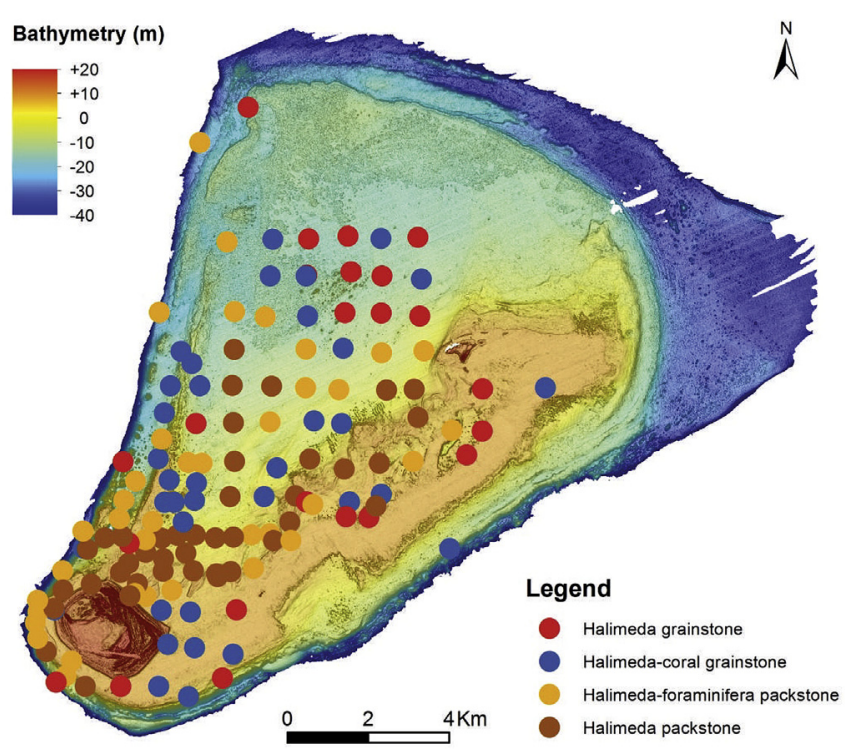

Fig. 10. Distribution of sedimentary facies at Glorieuses. Facies have been defined using cluster analysis (see methods for details).

$60 \mathrm{~m}$ deep reef terrace, and a shallower one at $22 \mathrm{~m}$ deep to an age ranging from $9.6 \mathrm{ka}$ (Zinke et al., 2003) to $9.1 \mathrm{ka}$ (Camoin et al., 2004). Zinke et al. (2003) considered ages of $8 \mathrm{ka}$ and $7 \mathrm{ka}$ for two other terraces recorded in Mayotte at $8 \mathrm{~m}$ and $5 \mathrm{~m}$ deep, respectively.

In a similar approach, the slopes from the Glorieuses display a succession of seabed morphologic structures (e.g. terraces, drowned reefs etc.) that seemingly reflect a complex past history of sea-level changes (Fig. 11). The Barbados record has demonstrated that the sea level was located at about $120 \mathrm{~m}$ below its present position during the Last Glacial Maximum (25-23 ka) at a time when there was 70\% more grounded ice on Earth (Fairbanks, 1989; Peltier and Fairbanks, 2006). The global sea-level rise, resulting from melting glaciers following the Last Glacial Maximum, did not occur uniformly, but was characterized by several centuries of extremely rapid sea-level rise (i.e. Meltwater Pulses) of about $20 \mathrm{~m}$

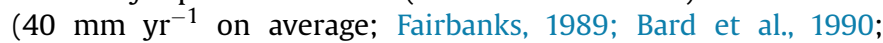
Fairbanks et al., 2005; Peltier and Fairbanks, 2006). However, uncertainties concerning the general pattern of the last deglacial sealevel rise remain because the apparent sea-level record may not be free of tectonic or isostatic complications. The architecture and geometry of reef systems that grew during the last deglacial sealevel rise, as illustrated in Glorieuses (Fig. 11), indicate that their development and growth modes were controlled by the progressive flooding of the slopes, the rate of sea-level rise, and the coeval increase in accommodation space (see review in Camoin and Webster, 2015). During periods of moderate rise in sea level and periods of stabilization in sea level, coral reefs were able to keep up with sea-level rise and reefs could develop in high energy zones of the islands. Faster rise in sea level (Meltwater Pulses) may have induced a backstepping and incipient drowning of reef systems (Camoin et al., 2012; Camoin and Webster, 2015) (Fig. 11).

As a result, the Glorieuses island slopes display three distinctive reef terraces respectively at $-80 \mathrm{~m},-60 \mathrm{~m}$, and $-35 \mathrm{~m}$, that probably reflect the last deglacial sea-level rise, while the exposed terrace at $+5 \mathrm{~m}$ above modern sea level probably corresponds to the Last Interglacial (Fig. 11). Considering the regional observations made on such typical slope-terraces at the same depths (Dullo et al., 1998; Zinke et al., 2003; Camoin et al., 2004) and the correlations with global sea-level records (Bard et al., 1990; Camoin et al., 2004; Alley et al., 2005; Bard et al., 2010; Deschamps et al., 2012; Camoin and Webster, 2014), we are able to propose ages for the different levels archived by corals flats and give-up. The sea-level stillstand or the decrease in sea-level rise during the Younger Dryas period $(12,700-11,600 \mathrm{ka})$ is worldwide imprinted, in this region and on the Glorieuses platform, by a well-defined terrace at about $60 \mathrm{~m}$ 


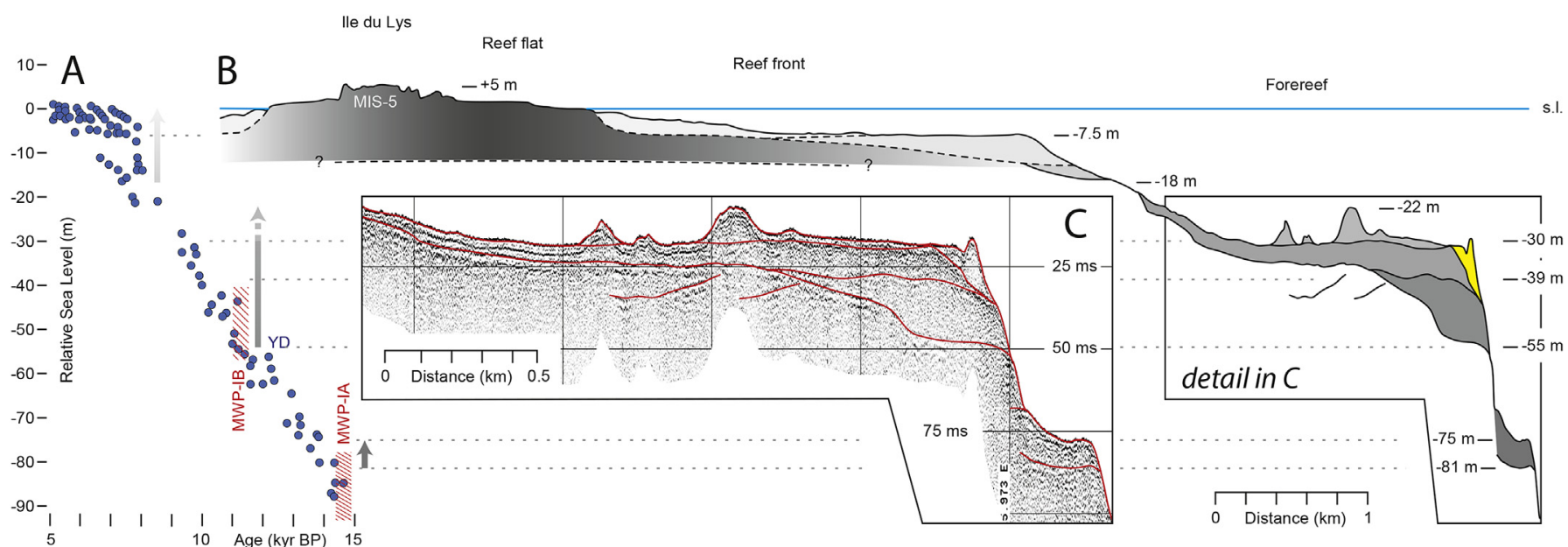

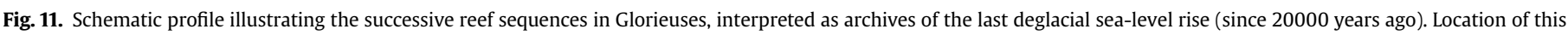

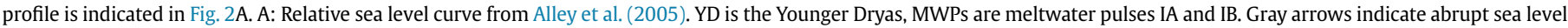

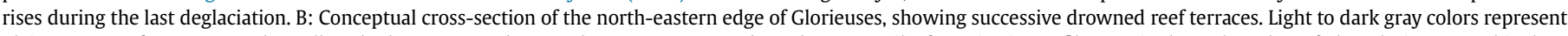

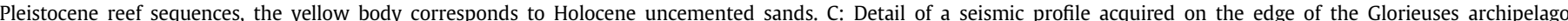

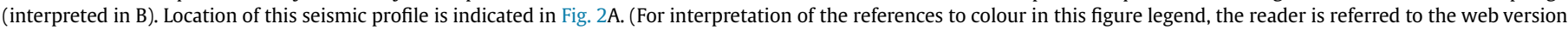
of this article.)

water depth (Fig. 11). The interpretation of the flat morphology observed at $-80 \mathrm{~m}$ is more widely discussed because this depth has been reached during several long periods of the last climate cycle. In comparison with Mayotte records (Dullo et al., 1998), we could then suggest two possible ages when this terrace may have been shaped: 1) a sea-level stillstand during the late isotopic stage 3 (at 55-24 ka) and 2) the Older Dryas period preceding the Meltwater Pulse 1A, i.e. before 14,6 ka (Deschamps et al., 2012). Finally, the shallower terrace at $-35 \mathrm{~m}$ should correspond to the Holocene flooding of the platform when sea-level reached the shelf edge around $10 \mathrm{ka}$ (Bard et al., 2010; Deschamps et al., 2012; Camoin and Webster, 2014). Based on these depth correlations with global sealevel records, the keep-up intervals between terraces (give-up reef levels) seem to be the results of period of increase in sea-level rise or Melwater Pulses, in particular between the Older and Younger Dryas (i.e. Meltwater Pulse 1A). In the future, dated samples will confirm that the Glorieuses slope-terraces reflect the last deglacial sea-level rise.

The recent investigation of the Last interglacial reef complex of the Glorieuses has suggested a negligible uplift rate of about $0.012 \mathrm{~mm} \mathrm{yr}^{-1}$ since the last $125 \mathrm{ka}$ (Guillaume et al., 2012) based on the elevation of the Last Intergacial terrace. However, there is still an ongoing debate regarding the timing, duration and amplitude of the highstand, as well as higher frequency sea-level oscillations that have occurred during that time window (Camoin and Webster, 2015). Based on a review of available sediment core and fossil coral data, Siddall et al. (2006) estimated the sea level position during the last interglacial was $3 \pm 1 \mathrm{~m}$. In contrast, Kopp et al. (2009) indicated that there was a 95\% probability that the last interglacial sea level was at least $6.6 \mathrm{~m}$ higher than present, and a $67 \%$ probability that it was higher than $8.0 \mathrm{~m}$ above current sea level, but thought it was unlikely to have exceeded $9.4 \mathrm{~m}$ (see Woodroffe and Webster, 2014 for recent review). The age and elevation variability of Last Interglacial reef deposits throughout the tropical realm probably reflect the effects of glacial isostatic adjustments (Muhs et al., 2011).

Despite the uncertainties regarding the exact elevation of the Last Interglacial terrace and regardless of isostatic adjustment influence which make any sea-level record relative, these data suggest a very limited regional tectonics control on the depths of the submerged terraces which, therefore, correspond to a unique record of past sea levels for the SW Indian Ocean. Modern reef flat would correspond to a period when sea level reached its present position, at $2.5 \mathrm{ka}$ (Camoin et al., 2004). As described in the Central Indian Ocean (Kench et al., 2009), the occurrence of indicators of a mid-Holocene highstand are probable but request further investigations.

The Glorieuses and Europa islands have also recorded periods of lower sea-level stands, probably during the last glacial cycle (e.g. between 80 and $20 \mathrm{ka}$ ), typified by karstic features such as the blue holes in Europa (Fig. 4A) and depressions observed in the Glorieuses modern reef flat (Fig. 6D). As observed in Hawaiian Islands (Grigg et al., 2002), depressions created by reef exposure during the last glacial maximum have been probably accentuated due to reef growth during the Holocene, in particular at Glorieuses. Conversely, blue holes occurring onland at Europa, which are located within last interglacial reefs, have never probably been reflooded during the last deglacial sea level rise.

\subsection{Future considerations}

Because the Glorieuses islands have archived submarine reef terraces that could be interpreted as a record of the last deglacial sea-level rise, further drilling programs dedicated to drowned reef terraces in that region will ground-truth our current understanding of how carbonate platforms have evolved since the last glacial maximum and, in particular, will provide a unique opportunity to fully test the model that evolution of modern reefs is linked to the occurrence of Meltwater Pulses throughout the last deglaciation (Alley et al., 2005; Clark et al., 2004; Fairbanks, 1989; Weaver et al., 2003; Yokoyama et al., 2000).

The Glorieuses archipelago would constitute an ideal location to address such fundamental questions for several reasons, of which two stand out. The first is that the Glorieuses can be considered a unique natural laboratory for studying pure carbonate systems. In spite of its short extent, reefs are established far from the coast and are devoid of siliciclastic sediments. The second reason is that, very recently, a controversy concerning the existence of Meltwater Pulse 1B (occurring after the Younger Dryas stillstand) has emerged. The Barbados records suggest that the last deglaciation was punctuated 
by two brief intervals of extremely rapid sea-level rise, i.e., Meltwater Pulse 1A and Meltwater Pulse 1B (Bard et al., 1990; Fairbanks, 1989; Peltier and Fairbanks, 2006). The new Tahiti sea-level record shows that the sea-level rise slowed during the Younger Dryas and accelerated again during the Holocene (Bard et al., 2010). The Tahiti reef record does not support the occurrence of an abrupt reef drowning event coinciding with a sea-level pulse of $\sim 15 \mathrm{~m}$, and implies an apparent rise of $40 \mathrm{~mm} \mathrm{yr}^{-1}$ during the time interval corresponding to Meltwater Pulse 1B in Barbados (Bard et al., 2010; Camoin et al., 2012). Drillings of drowned reefs at Glorieuses would help to decipher the behavior of SW Indian Ocean reefs facing relative sea-level rise during the last deglaciation, and to compare with far-field records.

\section{Conclusions}

The analysis of the sediment composition and the distribution of the various skeletal components in the Glorieuses, Juan de Nova and Europa islands, helps in the understanding of the modern functioning of small carbonate systems. The sediment composition is characterized by the prevalence of four main components corals, green algae, molluscs and foraminifers, among which corals are the most abundant ones on Europa islands and display the largest quantities in shallow marginal areas. Green algae, molluscs and foraminifers occur preferentially in deeper water setting like in Glorieuses and Juan de Nova. Main factors influencing this basic pattern are the distribution of carbonate production sites which is specific to the three islands, and the reworking of grains by local hydrodynamics (tide and fair weather waves) and by exceptional events such as storms.

Drowned terraces and emerged fossil reefs from the Glorieuses archipelago represent a potential unique record of past sea levels for the SW Indian Ocean. The occurrence of Last interglacial reefs at about $5 \mathrm{~m}$ above modern sea level, suggests very limited tectonic movements of the Glorieuses seamount since that period. Karstic cavities preserved in the modern reef flat are interpreted as relics of dissolution cavities formed during the subaerial exposure of the platform, when sea level drop $120 \mathrm{~m}$ below modern sea level, corresponding to the Late Glacial cycle. Submerged terraces (80 m-35 m water depth) are the expression of the last deglacial sea-level rise. The latter will be further investigated during forthcoming surveys in order to define drilling targets.

\section{Acknowledgments}

This research was supported by France's "Iles Eparses" program (2011-2013) managed by CNRS-InEE (Institut Ecologie et Environnement) with the financial support of CNRS-InEE, CNRS-INSU (Institut National des Sciences de l'Univers), IRD (Institut de Recherche pour le Développement), AAMP (Agence des Aires Marines Protégées) and the logistic support of TAAF (Terres Australes et Antarctiques Françaises). Additional funding was provided by CEREGE and the OSU Pythéas, IFREMER (Project "Sedimentary Systems"), LabexMER (ANR-10-LABX-19-01), and TOTAL Research \& Development (FR00006152). We are grateful to Captain, Officers, and TAAF (Terres Australes et Antarctiques Françaises) crew members of the 2011 Iles Eparses cruise on the R/V Marion Dufresne for their technical support in recovering first marine and terrestrial data and observations. This first cruise in Iles Eparses would not have been possible without the collaboration of Michel Guillemard (TSMOI, Indian Ocean Submarine Works) and the Apogon boat. We are also indebted to Nicolas and Anne Tisnee for the logistical supports onboard the Anstiva vessel during the second 2013 cruise. Vincent Lamarre and Yves Pastol (SHOM, French Marine Oceanographic and Hydrographic Service) are acknowledged for their collaboration regarding Litto3 $\mathrm{D}^{\odot}$ data. Two anonymous reviewers, Editor Jorge Gutierrez and Program Director Marc Trousselier are acknowledged for constructive comments and review. We warmly thank Alison Chalm (IFREMER) for English improvement on the last version of the manuscript.

\section{References}

Adjas, A., Masse, J.-P., Montaggioni, L.F., 1990. Fine-grained carbonates in nearly closed reef environments: Mataiva and Takapoto atolls, Central Pacific Ocean. Sediment. Geol. 67, 115-132.

Alley, R.B., Clark, P.U., Huybrechts, P., Joughin, I., 2005. Ice-sheet and sea-level changes. Science 310, 456-460.

Bard, E., Hamelin, B., Fairbanks, R.G., Zindler, A., 1990. Calibration of the C-14 timescale over the past 30,000 years using mass-spectrometric U-Th ages from Barbados corals, Nature 345, 405-410.

Bard, E., Hamelin, B., Delanghe-Sabatier, D., 2010. Deglacial meltwater pulse 1B and Younger Dryas sea levels revisited with boreholes at Tahiti. Science 327 1235-1237.

Bardintzeff, J.M., Liégeois, J.P., Bonin, B., Bellon, H., Rasamimanana, G., 2010 Madagascar volcanic provinces linked to the Gondwana break-up; geochemical and isotopic evidences for contrasting mantle sources. Gondwana Res. 18 295-314.

Battistini, R., Cremers, G., 1972. Geomorphology and vegetation of Iles Glorieuses. Atoll Res. Bull. 159, 1-10.

Battistini, R., Gayet, J., Jouannic, C., Labracherie, M., Peypouquet, J.P., Pujol, C., PujosLamy, A., Turon, J.L., 1976a. Etude des sédiments et de la microfaune des îles Glorieuses (Canal du Mozambique). Cah. ORSTOM Ser. Géol. 2, 147-171.

Battistini, R., Lalou, C., Elbez, G., 1976b. Datation par la méthode 230Th/234U du Pléistocène moyen marin de Madagascar et des îles voisines. C. R. Soc. Géol. Fr. 5, 201.

Bourjea, J., Nel, R., Jiddawi, N.S., Koonjul, M.S., Bianchi, G., 2008. Sea turtle bycatch in the West Indian Ocean; review, recommendations and research priorities. West. Indian Ocean J. Mar. Sci. 7, 137-150.

Camoin, G.F., Montaggioni, L.F., Braithwaite, C.J.R., 2004. Late glacial to post glacial sea levels in the Western Indian Ocean. Mar. Geol. 206, 119-146.

Camoin, G.F., Seard, C., Deschamps, P., Webster, J.M., Abbey, E., Braga, J.C., Iryu, Y Durand, N., Bard, E., Hamelin, B., Yokoyama, Y., Thomas, A.L., Henderson, G.M. Dussouillez, P., 2012. Reef response to sea-level and environmental changes during the last deglaciation: Integrated Ocean Drilling Program Expedition 310, Tahiti Sea Level. Geology 40, 643-646.

Camoin, G.F., Webster, J., 2014. Coral reefs and sea-level change. In: Stein, R. Blackman, D.K., Inagaki, F., Larsen, H.-C. (Eds.), Earth and Life Processes Discovered from Subseafloor Environment - a Decade of Science Achieved by the Integrated Ocean Drilling Program (IODP). Series Developments in Marine Geology. Elsevier, Amsterdam/New York, pp. 395-441.

Camoin, G.F., Webster, J., 2015. Coral reef response to quaternary sea-level and environmental changes: state of the science. Sedimentology 62, 401-428.

Clark, P.U., Dyke, A.S., Shakun, J.D., Carlson, A.E., Clark, J., Wohlfarth, B., Mitrovica, J.X., Hostetler, S.W., McCabe, A.M., 2009. The last glacial maximum. Science 325, 710-714.

Clark, P.U., Marshall McCabe, A., Mix, A.C., Weaver, A.J., 2004. Rapid rise of sea level 19,000 years ago and its global implications. Science 304, 1141-1144.

Class, C., Goldstein, S.L., Altherr, R., Bachelery, P., 1998. The process of plumelithosphere interaction in the ocean basins - the case of Grande Cormore Island. J. Petrol. 39, 881-903.

Cutler, K.B., Edwards, R.L., Taylor, F.W., Cheng, H., Adkins, J., Gallup, C.D., Cutler, P.M., Burr, G.S., Bloom, A.L., 2003. Rapid sea-level fall and deep-ocean temperature change since the last interglacial period. Earth Planet. Sci. Lett. 206, 253-271.

Deschamps, P., Durand, N., Bard, E., Hamelin, B., Camoin, G., Thomas, A., Henderson, G., Okuno, J., Yokoyama, Y., 2012. Ice sheet collapse and sea-level rise at the Bølling warming, 14,600 yr ago. Nature 483, 559-564.

Droxler, A.W., Jorry, S.J., 2013. Deglacial origin of barrier reef along low-latitude mixed siliciclastic-carbonate shelf edges. Ann. Rev. Mar. Sci. 4, 163-190.

Droxler, A.W., Schlager, W., 1985. Glacial versus interglacial sedimentation rates and turbidite frequency in the Bahamas. Geology 13, 799-802.

Droz, L., Mougenot, D., 1987. Mozambique upper fan: origin of depositional units AAPG Bull. 17, 1355-1365.

Dullo, W.C., Camoin, G.F., Blomeier, D., Colonna, M., Eisenhauer, A., Faure, G., Casanova, J., Thomassin, B.A., 1998. Morphology and sediments of the foreslopes of Mayotte, Comoro Islands: direct observations from a submersible. Spec. Pub. Int. Assoc. Sedimentol. 25, 219-236.

Dunham, R.J., 1962. Classification of carbonate rocks according to depositional texture. AAPG Mem. 1, 108-121.

Edwards, R.L., Beck, J.W., Burr, G.S., Donahue, D.J., Chappell, J.M.A., Bloom, A.L. Druffel, E.R.M., Taylor, F.W., 1993. A large drop in atmospheric C-14/C-12 and reduced melting in the younger dryas, documented with Th-230 ages of corals. Science 260, 962-968.

Enos, P., 1974. Surface Sediment Facies of the Florida-Bahamas Plateau Map Series MC-5, fourth ed. Geological Society of America, Boulder, Colorado, USA.

Emery, K.O., Tracey, J.I., Ladd, H.S., 1954. Geology of Bikini and Nearby Atolls: Part 1, Geology. U.S. Geol. Surv. 265. Prof. Pap. 260-A. 
Emerick, C.M., Duncan, R.A., 1982. Age progressive volcanism in the Comores archipelago, western Indian Ocean and implications for Somali plate tectonics. Earth Planet. Sci. Lett. 60, 415-428.

Fairbanks, R.G., 1989. A 17,000-year Glacio-Eustatic sea-level record - influence of glacial melting rates on the younger dryas event and deep-ocean circulation. Nature 342, 637-642.

Fairbanks, R.G., Mortlock, R.A., Chiu, T.C., Cao, L., Kaplan, A., Guilderson, T.P., Fairbanks, T.W., Bloom, A.L., Grootes, P.M., Nadeau, M.J., 2005. Radiocarbon calibration curve spanning 0 to 50000 years BP based on paired ${ }^{230} \mathrm{Th} /{ }^{234} \mathrm{U} /{ }^{238} \mathrm{U}$ and ${ }^{14} \mathrm{C}$ dates on pristine corals. Quat. Sci. Rev. 24, 1781-1796.

Gaven, C., Vernier, E., 1979. Datation Io-U de coraux et paleogeodynamique du Pleistocene moyen des Iles Glorieuses (Canal du Mozambique). Quaternaria 21, 45-52.

Ginsburg, R.N., 1956. Environmental relationships of grain size and constituent particles in some south Florida carbonate sediments. AAPG Bull. 40, 2384-2427.

Gischler, E., 2006. Sedimentation on Rasdhoo and Ari Atolls, Maldives, Indian Ocean. Facies 52, 341-360.

Gischler, E., 2011. Sedimentary facies of Bora Bora, Darwin's type barrier reef (Society Islands, South Pacific): the unexpected occurrence of non-skeletal grains. J. Sediment. Res. 81, 1-17.

Gledhill, D.K., Wanninkhof, R., Millero, F.J., Eakin, C.M., 2008. Ocean acidification of the greater Caribbean region, 1996-2006. J. Geophys. Res. 113 http://dx.doi.org/ 10.1029/2007JC004629. C10031.

Grigg, R.W., Grossman, E.E., Earle, S.A., Gittings, S.R., Lott, D., McDonough, J., 2002 Drowned reefs and antecedent karst topography, Au'au Channel, S.E. Hawaiian Islands. Coral Reefs 21, 73-82.

Gross, G.M., Milliman, J.D., Tracey, J.I., Ladd, H.S., 1969. Marine geology of Kure and Midway atolls, Hawaii: a preliminary report. Pac. Sci. 23, 17-25.

Guillaume, M.M.M., Reyss, J.L., Pirazzoli, P.A., Bruggemann, J.H., 2012. Tectonic stability since the last interglacial offsets the Glorieuses Islands from nearby Comoros archipelago. Coral Reefs. http://dx.doi.org/10.1007/s00338-012-10069.

Hammer, Ø., Harper, D.A.T., Ryan, P.D., 2001. PAST: paleontological statistics software package for education and data analysis. Palaeontol. Electron. 4, 1-9.

Hohenegger, J., Yordanova, Nakano, Y., Tatzreiter, F., 1998. Habitats of larger foraminifera on the upper reef slope of Sesoko Island, Okinawa. Jpn. Mar. Micropaleontol. 36, 109-168.

Hottinger, L., Halicz, E., Reiss, Z., 1991. The foraminiferal genera Pararotalia, Neorotalia, and Calcarina; taxonomic revision. J. Paleontol. 65, 18-33.

Jorry, S.J., Hasler, C.A., Davaud, E., 2006. Hydrodynamic behaviour of nummulites: implications for depositional models. Facies 52, 221-235.

Jorry, S.J., Droxler, A.W., Francis, J.M., 2011. Deepwater carbonate deposition in response to re-flooding of carbonate bank and atoll-tops at glacial terminations. Quat. Sci. Rev. 29, 2010-2026.

Jorry, S.J., Droxler, A.W., Mallarino, G., Dickens, G.R., Bentley, S.J., Beaufort, L. Peterson, L.C., Opdyke, B.N., 2008. Bundled turbidite deposition in the centra Pandora Trough (Gulf of Papua) since Last Glacial Maximum: linking sediment nature and accumulation to sea level fluctuations at millennial timescale. J. Geophys. Res. Earth Surf. 113 http://dx.doi.org/10.1029/2006JF000649. F01S19.

Kendall, C.G.S.C., Schlager, W., 1981. Carbonates and relative changes in sea-level. Mar. Geol. 44, 181-212.

Kench, P.S., Smithers, S.G., McLean, R.F., Nichol, S.L., 2009. Holocene reef growth in the Maldives: evidence of a mid-Holocene sea-level highstand in the centra Indian Ocean. Geology 37, 455-458.

Kolla, V., Kostecki, J.A., Henderson, L., Hess, L., 1980. Morphology and quaternary sedimentation of the Mozambique fan and environs, southwestern Indian Ocean. Sedimentology 27, 357-378.

Kopp, R.E., Simons, F.J., Mitrovica, J.X., Maloof, A.C., Oppenheimer, M., 2009. Probabilistic assessment of sea level during the last interglacial stage. Nature 462, 863-868.

Lambeck, K., Chappell, J., 2001. Sea level change through the last glacial cycle. Science 292, 679-686.

Lee, K., Tong, L.T., Millero, F.J., Sabine, C.L., Dickson, A.G., Goyet, C., Park, G.-H., Wanninkhof, R., Feely, R.A., Key, R.M., 2006. Global relationships of total alkalinity with salinity and temperature in surface waters of the world's oceans. Geophys. Res. Lett. 33 http://dx.doi.org/10.1029/2006GL027207. L19605.

Masse, J.-P., Thomassin, B.A., Acquaviva, M., 1989. Bioclastic sedimentary environments of coral reefs and lagoon around Mayotte island (Comoro Archipelago, Mozambique Channel, SW Indian Ocean). J. Coast. Res. 5, 419-432.

Maugé, L.A., Segoufin, J., Vernier, E., Froget, C., 1982. Géomorphologie et origine des bancs du Nord-est du Canal du Mozambique - Océan Indien occidental. Mar. Geol. 47, 37-55.

Maxwell, W.G.H., 1973. Sediments of the Great Barrier Reef Province. In: Jones, O.A., Endean, R. (Eds.), Biology and Geology of Coral Reefs, vol. 1. Academic Press, New York, pp. 299-345.

Muhs, D.R., Simmons, K.R., Schumann, R.R., Halley, R.B., 2011. Sea-level history of the past two interglacial periods: new evidence from U-series dating of reef corals from south Florida. Quat. Sci. Rev. 30, 570-590.

Müller, R., Sdrolias, M., Gaina, C., Roest, W.R., 2008. Age, spreading rates, and spreading asymmetry of the world's ocean crust. Geochem. Geophys. Geosys. 9 Q04006. http://dx.doi.org/10.1029/2007GC001743.

Newell, N.D., 1956. Geological reconnaissance of Raroia (Kon Tiki) Atoll, Tuamotu Archipelago. Am. Mus. Nat. Hist. Bull. 109, 311-372.

Parker, J.H., Gischler, E., 2011. Modern foraminiferal distribution and diversity in two atolls from the Maldives, Indian Ocean. Mar. Micropaleontol. 78, 30-49.

Peltier, W.R., Fairbanks, R.G., 2006. Global glacial ice volume and Last Glacial Maximum duration from an extended Barbados sea level record. Quat. Sci. Rev. 25, 3322-3337.

Purdy, E.G., 1963. Recent calcium carbonate facies of the Great Bahama Bank. 1. Petrography and reaction groups; 2 . Sedimentary facies. J. Geol. 71, 334-355.

Purdy, E.G., Gischler, E., 2003. The Belize margin revisited. 1. Holocene marine facies. Int. J. Earth Sci. 92, 532-551.

Rankey, E.C., Reeder, S.L., 2011. Controls on platform-scale patterns of surface sediments, shallow Holocene platforms, Bahamas. Sedimentolology 57, 1545-1565.

Rasamimanana, G., Bardintzeff, J.-M., Rasendrasoa, J., Bellon, H., Thouin, C., Gioan, P., Piqué, A., 1998. Les épisodes magmatiques du Sud-Ouest de Madagascar (bassin de Morondava), marqueurs des phénomènes de rifting crétacé et néogène. $C$. $R$. Acad. Sci. Ser. IIA Earth Planet. Sci. 326, 685-691. http://dx.doi.org/10.1016/ S1251-8050(98)80179-1.

Reijmer, J.J.G., Swart, P.K., Bauch, T., Otto, R., Roth, S., Zechel, S., 2009. A reevaluation of facies on Great Bahama Bank I: new facies maps of Western Great Bahama Bank. In: Swart, P.K., Eberli, G.P., McKenzie, J.A. (Eds.), Perspectives in Carbonate Geology: a Tribute to the Career of Robert Nathan Ginsburg, vol. 41. Int. Assoc. Sedimentol., Spec. Publ., pp. 29-46

Schlager, W., Reijmer, J.J.G., Droxler, A.W., 1994. Highstand shedding of carbonate platforms. J. Sediment. Res. 64, 270-281.

Siddall, M., Rohling, E.J., Almogi-Labin, A., Hemleben, C., Meischner, D., Schmelzer, I., Smeed, D.A., 2003. Sea-level fluctuations during the last glacial cycle. Nature $423,853-858$

Siddall, M., Chappell, J., Potter, E.K., 2006. Eustatic sea level during past interglacials. In: Sirocko, F., Clausen, M., Sanchez-Goni, M.F., Litt, T. (Eds.), The Climate of Past Interglacials. Elsevier, Amsterdam, pp. 75-92.

Storey, M., Mahoney, J.J., Saunders, A.D., Duncan, R.A., Kelley, S.P., Coffin, M.F., 1995. Timing of hot spot-related volcanism and the breakup of Madagascar and India. Science 267, 852-855.

Thompson, W.G., Goldstein, S.L., 2005. Open-system coral ages reveal persistent suborbital sea-level cycles. Science 308, 401-404.

Thorp, E.M., 1936. The sediments of the pearl and Hermes Reef. J. Sediment. Petrol. 6, 109-118.

Tudhope, A.W., Scoffin, T.P., Stoddart, D.R., Woodroffe, C.D., 1985. Sediments of Suwarrow Atoll. In: 5th Int. Coral Reef Symp., Tahiti, Proc., vol. 6, pp. 611-616.

Weaver, A.J., Saenko, O.A., Clark, P.U., Mitrovica, J.X., 2003. Meltwater pulse 1A from Antarctica as a trigger of the Bølling-Allerød warm interval. Science 299, 1709-1713.

Woodroffe, C.D., Webster, J.M., 2014. Coral reefs and sea-level change. Mar. Geol. $352,248-267$.

Yamano, H., Miyajima, T., Koike, I., 2000. Importance of foraminifera for the formation and maintenance of a coral sand cay: Green Island, Australia. Coral Reefs 19, 51-58.

Yokoyama, Y., Lambeck, K., De Deckker, P., Johnston, P., Fifield, I.K., 2000. Timing of the last Glacial maximum from observed sea-level minima. Nature 406, 413-416.

Zinke, J., Reijmer, J.J.G., Thomassin, B.A., Dullo, W.- Chr, Grootes, P.M., Erlenkeuser, H., 2003. Postglacial flooding history of Mayotte (Comoro archipelago, southwest indian ocean). Mar. Geol. 194, 181-196. 